\title{
Mechanisms initiating fluid migration at Snøhvit and Albatross fields, Barents Sea
}

\author{
Alexandros Tasianas $^{1} \cdot$ Iver Martens $^{1} \cdot$ Stefan Bünz $^{1} \cdot$ Jürgen Mienert $^{1}$
}

Received: 3 June 2016/Accepted: 31 October 2016/Published online: 21 November 2016

(C) Springer-Verlag Berlin Heidelberg 2016

\begin{abstract}
The southwestern Barents Sea, part of the epicontinental Barents Sea located between Norway and the Svalbard archipelago, hosts several mature petroleum systems. Large gas chimneys, leaking faults and seabed pockmarks are proof that hydrocarbon leakage has taken place previously in this part of the Barents Sea. Glacial erosion, being one of the major episodes of erosion and uplift, has probably caused fluid leakage out of proven hydrocarbon reservoirs and fluid migration along permeable carrier beds. We use 3D seismic data from the Snøhvit gas field to focus on the nature of the fluid transport systems and the origins and potential mechanisms for how fluids migrated from deep-seated reservoirs. Mapping of the trap of the reservoirs at Snøhvit has allowed us to determine potential spill point locations, coinciding with major gas chimneys and several faults that extend into shallow strata. We explain how uplift and erosion caused gas expansion in the reservoirs allowing the gas to reach below the spill point located at the gas-water contact level at the bottom of the closure. Fluids, such as hydrocarbons, may have escaped through these spills points, leading to the emplacement and development of the aforementioned gas chimneys. Similarly, migration of fluids may have taken place along faults, reactivated by glaciotectonic processes and connected with spill points at reservoir depth. Both gas chimneys and faults have allowed gas to migrate into and be trapped in shallow gas accumulations
\end{abstract}

Alexandros Tasianas

alexandros.tasianas@uit.no

1 Department of Geosciences, CAGE-Centre for Arctic Gas Hydrate, Environment and Climate, UiT the Arctic University of Norway in Troms $\varnothing, 9037$ Troms $\varnothing$, Norway within the Torsk Formation and below the upper regional unconformity.

Keywords Fluid migration - Gas chimney - Shallow gas · Barents Sea $\cdot$ Snøhvit gas field

\section{Introduction}

This piece of work deals with the spill point leakage history of the Snøhvit area in the Barents Sea. It is based on a good 3D seismic dataset and provides new insights into the mechanisms and processes of fluid leakage from reservoir edges and spill points in a study area that includes the Snøhvit and Albatross hydrocarbon fields in the Barents Sea.

The Barents Sea borders the Norwegian Sea in the west and the Arctic Ocean in the north and covers approximately an area of 1.4 million $\mathrm{km}^{2}$ (Fig. 1) [19, 78]. The average depth is $230 \mathrm{~m}$ with a maximum depth reaching $500 \mathrm{~m}$ in the western entrance to the Barents Sea (Fig. 1c) $[36,60,78]$.

Vertical fluid flow through marine sediments occurs on passive and active continental margins and is associated with excess pore fluid pressure [6, 7]. Hydrocarbon leakage associated with focused fluid flow, both in the subsurface and at the seabed, is a common phenomenon in many sedimentary basins all around the world [31]. The process of focused fluid flow may cause pockmarks, mud volcanoes and methane-derived carbonate mounds on the seabed. Indeed, large parts of the southwestern Barents Sea study area are characterized by a high density of pockmarks [66].

In seismic data, fluid flow features are commonly recognized as blow-out pipes, vertical seismic chimneys, palaeo-pockmarks and amplitude anomalies [3, 29, 31, 46]. 
a

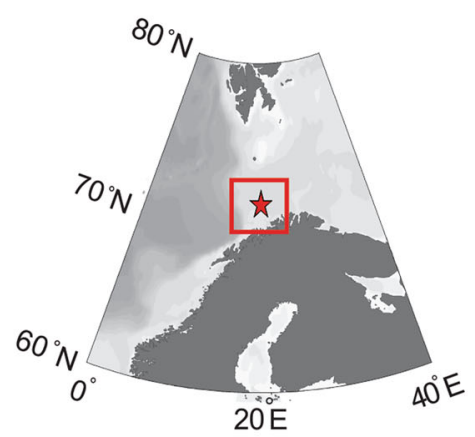

C

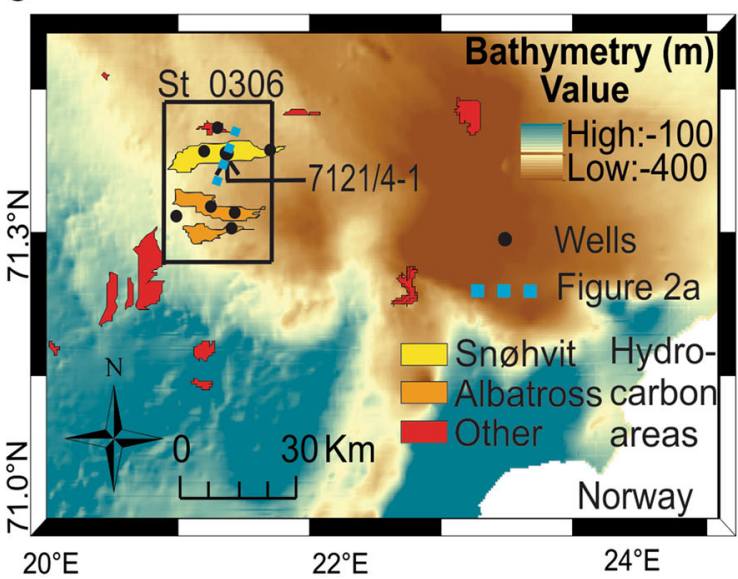

b

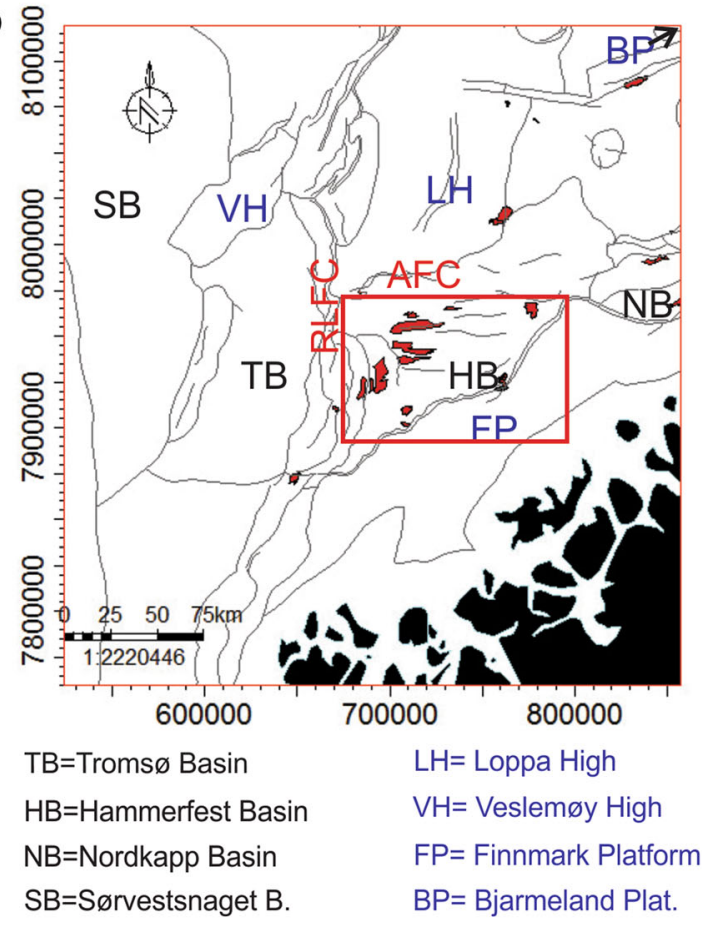

AFC=Asterias Fault Complex

RLFC=Ringvassøy-Loppa Fault Complex

Coordinate Reference System: ED50-UTM33

Fig. 1 a The figure shows the location of the study area, b the figure shows the main structural elements in the SW Barents Sea and $\mathbf{c}$ the figure corresponds to an overview of the study area showing 3D cube ST0306 and well locations

Depending on the setting, gas or fluid seepage may or may not be observed from these pockmarks. In the UK-North Sea sector, for example, there is continuous gas seepage from seabed pockmarks. However, in the Troll gas production field located at c. $1500 \mathrm{~m}$ depth below the seafloor, offshore Norway, gas or fluid seepage has never been observed during the numerous seafloor mapping and inspection surveys carried out over the last three decades $[31,66]$. For assessing the possibility of present day pockmark seepage and deep reservoir leakage occurrence, it is important to consider the many factors that control whether or not fluid migration will occur all the way to the seafloor and whether or not pockmarks will be formed at all.

Leakage and migration of hydrocarbons, in response to uplift and erosion, has been observed to lead to fluid migration into shallow sediments and seepage into the ocean through the seafloor $[15,16,27]$. Moreover, leakage originating from other mechanisms, such as hydraulic leakage and diffusive/molecular transport, could also cause fluids to migrate into shallower depths $[32,35]$. Any such possible leakage can have potential effects on seabed (benthic) ecosystems [14], marine ecosystems and even on the global climate if the seeping gas reaches the atmosphere $[26,71]$. It is important to determine the nature of the seeping gas when assessing its potential impact on the global climate as the global warming potential of methane, for example, is regarded 72 times more effective than that for the same amount of $\mathrm{CO}_{2}$ [76].

Shallow gas, gas hydrates and seafloor expulsion features, such as channel structures, pockmarks and mud volcanoes, occur in several areas of the SW Barents Sea $[1,11,12,37,58,59,61]$. Many fluid flow features in the subsurface and at the seafloor of the Snøhvit and Albatross areas include zones of chaotic low-amplitude seismic, discontinuous reflections in the seismic records, areas of high amplitude anomalies, vertical fluid flow features and shallow gas accumulations [10, 31, 58, 82]. Much of the fluid flow has been associated with the Cenozoic denudation, or in other words erosion, of the Barents Sea. Cenozoic erosion and uplift may have caused a slight northward tilt of the Finnmark Platform and depletion of hydrocarbon accumulations and remigration in the Barents Sea [27, 55]. This Cenozoic erosion is not related to glaciations. However, in the Barents Sea, glacial erosion has taken place and has affected, in a rapid and massive way, some areas of the SW Barents Sea. In the affected areas, the glaciers were characterized by an erosive nature and the glacial erosion mainly took place along their margins. 
However, a clear relationship has never been documented and the detailed mechanisms are not fully understood. This paper will mainly focus on introducing new insights for identifying and locating possible fluid pathways and leakage points in the Snøhvit and Albatross fields and the mechanisms and processes initiating fluid migration from reservoir edges and spill points.

We use conventional 3D seismic data to document the detailed mechanism of how fluids leaked from Snøhvit and Albatross hydrocarbon reservoirs in response to the glaciotectonic development and denudation history of the Barents Sea. As such, this work facilitates a better understanding of hydrocarbon systems and fluid flow, both shallow and deep, and related conduits, such as faults, fractures or vertical columnar zones leading to the accumulation of fluids in the shallow subsurface. This study is also important for improving risk assessment of the storage of $\mathrm{CO}_{2}$ in subsurface formations in the Barents Sea.

\section{Geological setting and study area}

\section{Depositional environment and stratigraphy}

The Middle to Upper Triassic strata, (manifested in the Kobbe, Snadd and Fruholmen Formations), contain a lower sequence of interbedded shales and sandstones which is overlain by a shaly and silty unit (Fig. 2). These sediments were deposited in a presumably deltaic environment of deposition [45]. The lower to Middle Jurassic strata, (manifested in the Tubåen, Nordmela and Stø Formations), contain mainly sandstones of varying grain size, interbedded with thin shale layers that were deposited in a shallow marine to coastal plain environment. After a major hiatus, the Upper Jurassic organic-rich shales (manifested in the Fuglen and Hekkingen Formations) were deposited in a marine shelf environment.

The Cretaceous sediments, of mainly claystones [45], were deposited in a marine shelf depositional environment. Deposition of the Knurr and Kolje Formations occurred during the lower Cretaceous (Fig. 2) [51]. The Knurr Formation is composed mainly of shale with sand and silt interbeds, whereas the Kolje Formation is described by high clay contents with thin interbeds of sandstones and siltstones [69]. The Kviting Formation consists of condensed calcareous units, deposited in a deep to shallow shelf, whereas the Kveite Formation consists of claystones deposited in a marine bathyal environment [51].

The Paleogene succession exhibits westward-dipping strata and consists of Paleocene to Eocene claystones of the Torsk Formation [45, 59]. It was deposited in a marine shelf environment, and after a major hiatus, corresponding to the Upper Regional Unconformity (URU); the Pliocene to Pleistocene sequence is represented by only $100 \mathrm{~m}$ of soft claystones (Fig. 2) [45, 59]. The URU erosional surface constitutes a lithological transition and can thus act as a barrier to fluid flow. In addition, the presence of dense and less permeable glacigenic sediments above the URU can act as an efficient trap preventing any fluid loss.

\section{Tectonic development}

The Barents Sea contains a number of basins and basement highs, such as the Loppa and Veslemøy Highs and the Finnmark platform (Fig. 1b), formed as a result of continental collisions [19]. Some of the dominant basins include the Troms $\varnothing$, Hammerfest, Nordkapp and Sørvestsnaget basins (Fig. 1b) [74].

The Hammerfest Sedimentary Basin (Fig. 1b) is bounded by the Finnmark Platform in the South, by the Loppa High in the North, the Ringvassøya Fault complex in the west and a flexure against the Bjarmeland Platform to the NE (Fig. 1b) (43). The Hammerfest Basin was probably initiated in the Upper Carboniferous, by extensional tectonics with the oldest tectonic event that can be mapped regionally occurring in the Upper Devonian-Lower Carboniferous time in response to the initial rifting between Greenland and Norway [5].

Such extensional tectonic activity caused tilting of the Loppa High and Hammerfest Basin in the Upper Carboniferous to Lower Permian and reactivation of the underlying basement fault trends. Furthermore, another three episodes of fault reactivation have been proposed for the study area, namely in Upper Jurassic, Lower Cretaceous and Lower Paleocene times [50]. The main subsidence events occurred in the Triassic and the Lower Cretaceous. Upper Permian and Lower Triassic extension also resulted in tilting and erosion of the crestal parts of the Loppa High, coinciding with the time of occurrence of the first major uplift. It is then during the mid-Cretaceous that a culmination of basinal development takes place [22].

Caledonian orogeny events, associated with compressive north-easterly directed movements $[56,79]$ were followed by periods of sinistral shear movements [18, 24]. These Caledonide-related tectonic movements led to the development of a system of weak fault zones in the western Barents Sea, namely the Ringvassøya fault complex, reactivated during later tectonic activity [19, 24].

The Paleogene begins with the onset of the spreading of the Norwegian-Greenland Sea, followed by the GreenlandSvalbard separation [19]. A series of faults that terminate below the URU, an erosional boundary that separates the upper consolidated sediments from the underlying bedrock, are observed from (Mid Paleocene-Lower Eocene) [59]. 
a

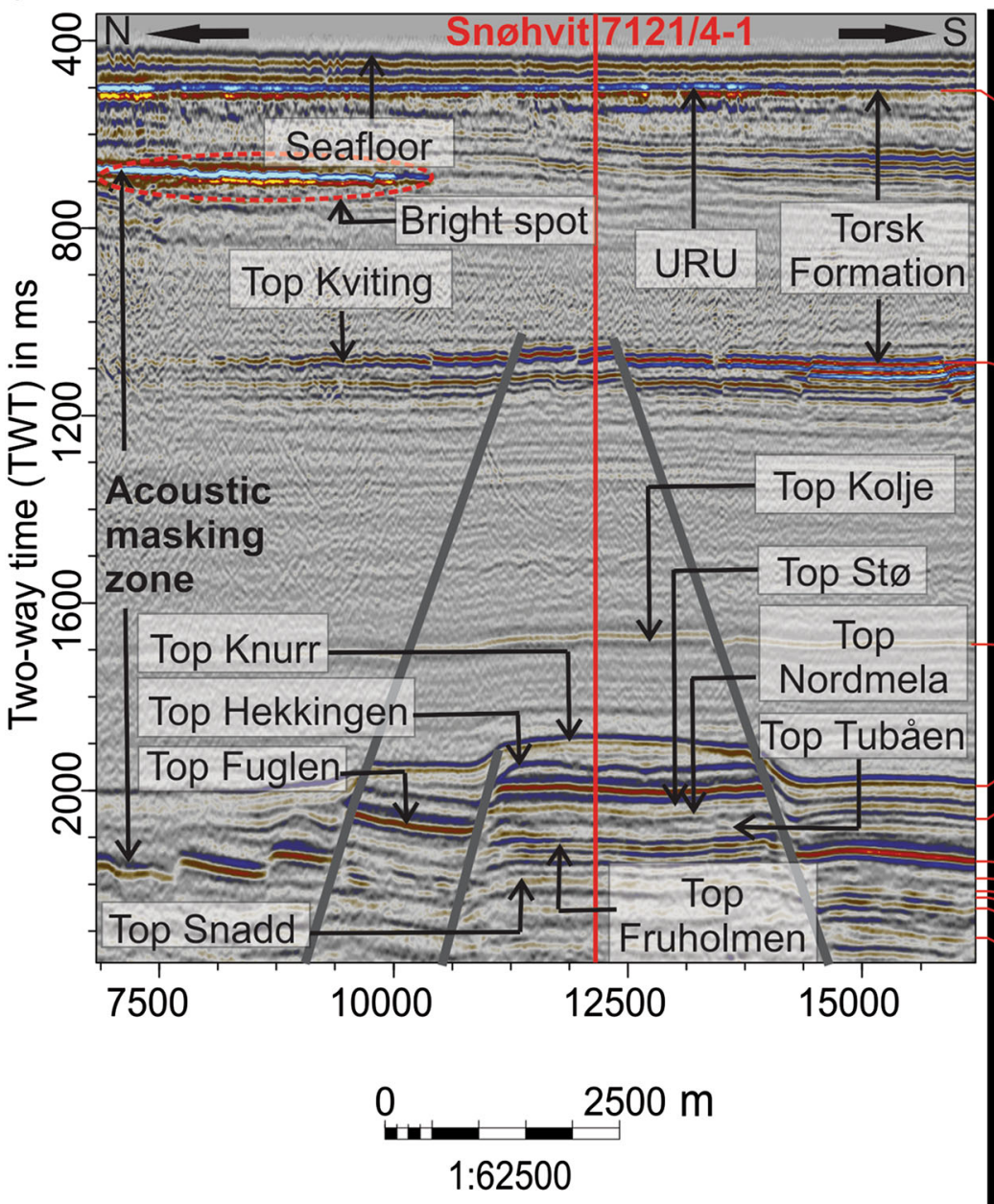

b

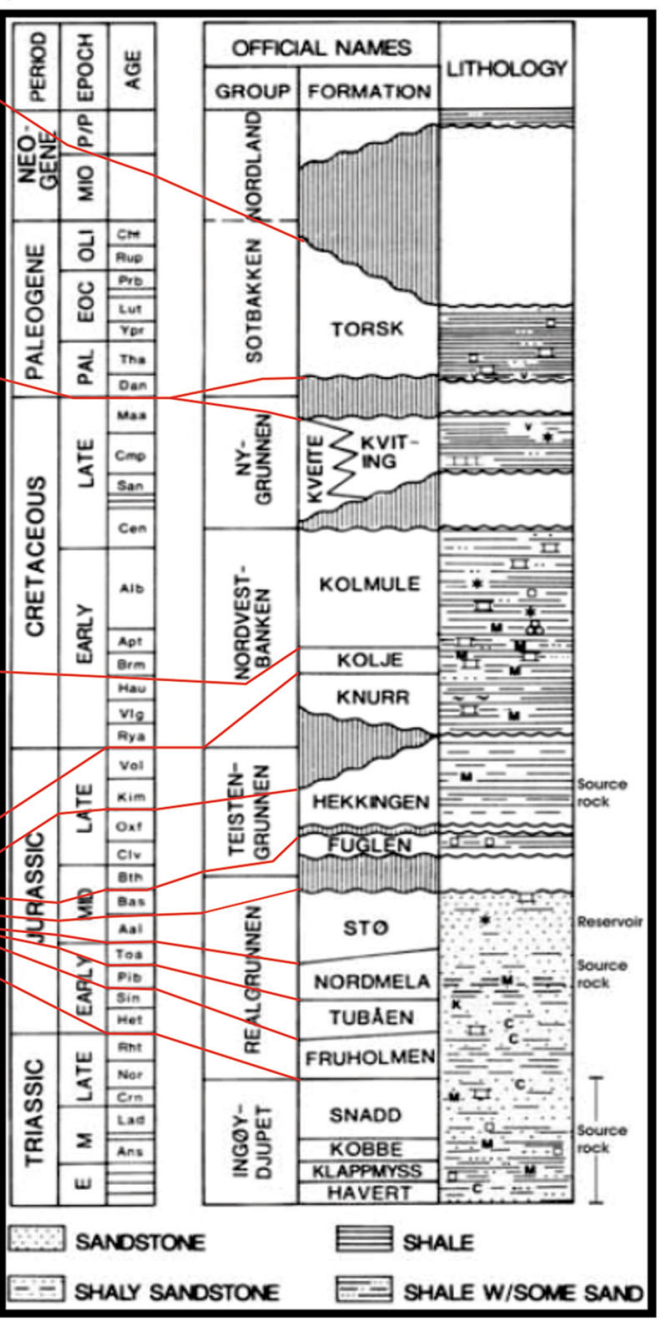

Fig. 2 a The figure shows seismic line 2706 from 3D seismic block ST0306 and b the figure shows the main age units down to 2,5 s TWT [45]

The existence of the URU suggests that extensive glacial erosion and deposition has taken place in the study area. The Paleocene-Eocene interval is also affected by first order faults $[9,59]$ and by a NS fault [59]. The first order faults penetrate into the Cretaceous and Paleocene-Lower Eocene strata and are sealed below the URU. They are differentiated from the second order faults, which do not affect this younger interval (Paleocene-Lower Eocene) and whose activity terminates in the Lower Cretaceous. The first order faults and the NS faults have been active since the (Kimmeridgian) tectonic phase and were later reactivated during the (Hauterivian-Barremian) tensional events $[5,22,59]$. The northern parts of the NS faults are characterized by minor rollover anticline structures at the (Cenomanian) and (Upper Paleocene) levels which are indicative of possible compression movements along the faults at that time [59].

\section{Fault orientations}

Three major fault orientations are observed in the area: EW, NE-SW and NW-SE (Fig. 3a, b). In the dataset, major deep-seated faults are observed (Fig. 3) with high amplitude anomalies often being located above their upper termination (Fig. 3a-c, f, g). Major faults are mainly normal faults with varying lateral extension, fault orientation and fault throw (Fig. 3). Faults with noticeable throw offsets into the Cretaceous and Tertiary generally show an E-W direction (Fig. 3) $[5,45,59]$. Faults with offsets up into the Upper Jurassic vary in strike directions from E-W to NESW to NW-SE, and have smaller fault throws than their younger, mostly E-W striking counterparts (Fig. 3a, b). Block faulting is common due to the parallel or nearly parallel strike and dip directions of some of the faults (Figs. 2, 3). The structural basis for the Snøhvit reservoir is 

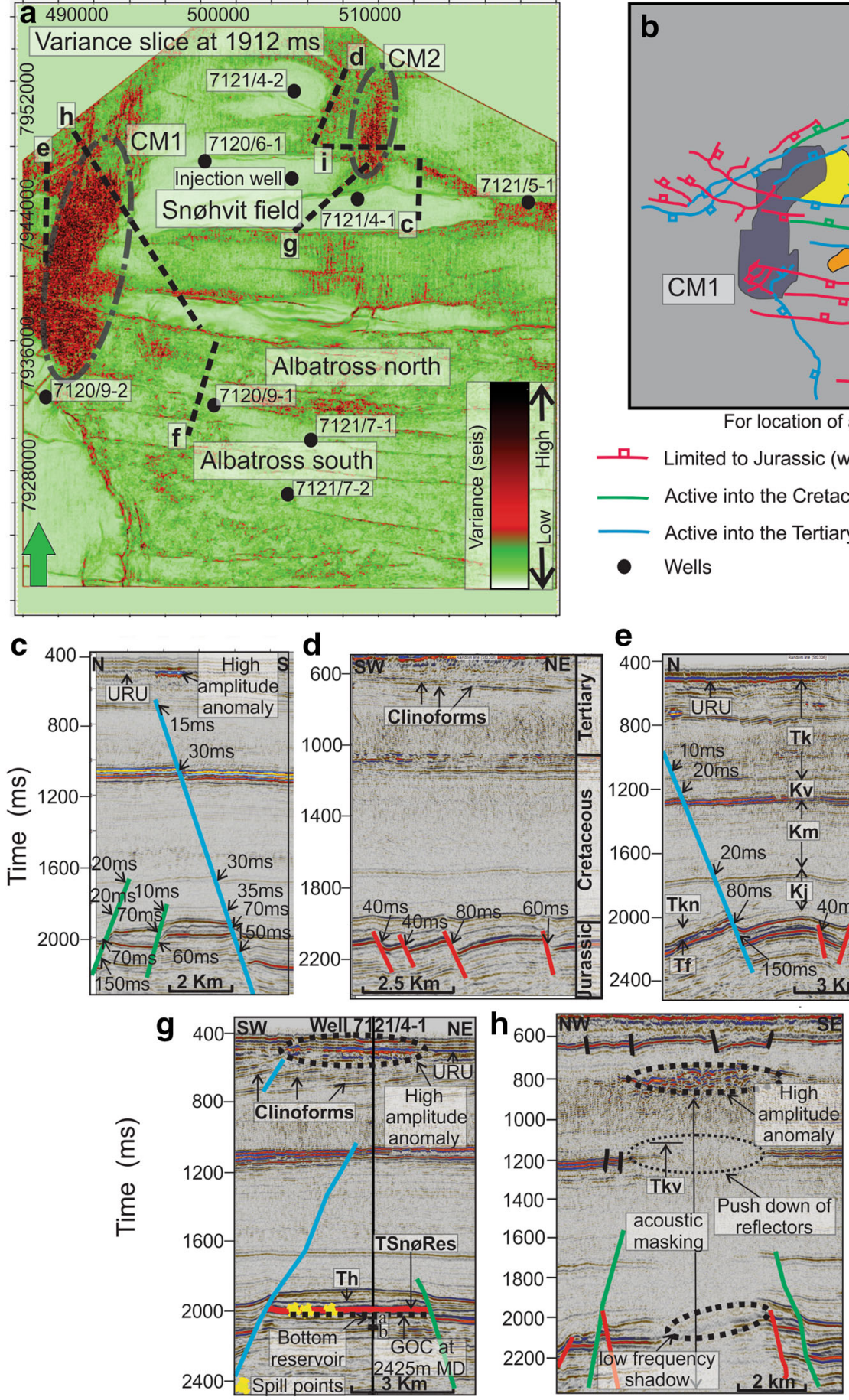

Active into the Cretaceous

- Wells

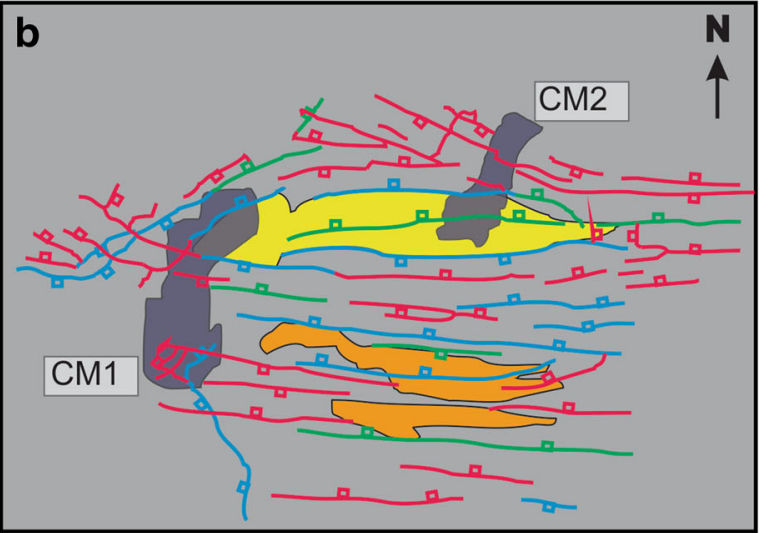

For location of area see black rectangle in Fig. 1c

- L Limited to Jurassic (with dip direction)

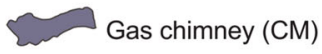

$\sim$ Snohvit field

$\oiiint$ Albatross field

$10 \mathrm{Km}$

$800-$
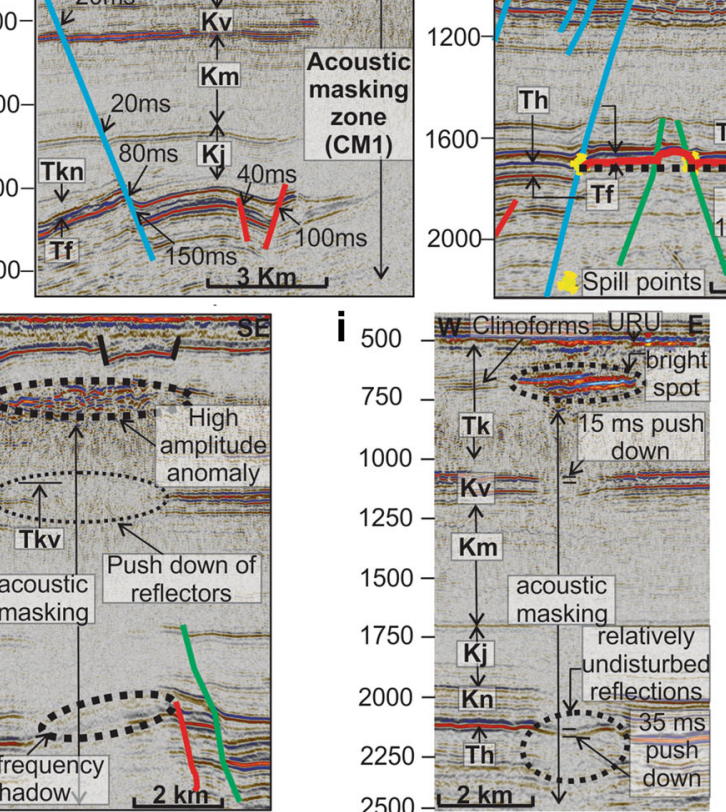

Fig. 3 a The figure corresponds to a variance map at $-1912 \mathrm{~ms}$ depth (near the top of the reservoir level) with various cross section locations $\mathbf{c}-\mathbf{i}, \mathbf{b}$ the figure illustrates the pattern of large-scale faulting derived from fault positions in the Fuglen formation. The pattern is based on 3D seismic dip map and seismic section interpretations. Faults limited to the Jurassic (red colored) will be called Jurassic faults and faults active into the Cretaceous (green colored) and into the Tertiary (blue colored) will be called Cretaceous and Tertiary faults, respectively. c seismic cross section through Cretaceous and Tertiary faults, $\mathbf{d}$ seismic cross sections through Jurassic faults, e The seismic cross section highlights various faults and CM1. f The figure illustrates the association of faults and spill points at Albatross field and $\mathbf{g}$ the figure shows the association of faults and spill points at Snøhvit reservoir (a Nordela Formation and b Tubåen Formation) and $\mathbf{h}$ the figure corresponds to a seismic example of CM1 gas chimney. For seismic line locations (c-i). See a Formation and Formation top abbreviations $T k$ Torsk Formation, $K v$ Kviting formation, $K m$ Kolmule Formation, $K j$ Kolje Formation, $K n$ Knurr Formation, $T k v$ Top Kviting, Tkn Top Knurr, Tf Top Fuglen, Th Top Hekkingen, TAlbRes Top Albatross reservoir, TSn $\phi$ Res Top Snøhvit reservoir (St $\varnothing$ Formation) 
defined by two major horst structures bounded by E-W trending faults, (Figs. 2, 3a, b, 4) [45].

\section{Petroleum systems}

The Snøhvit and Albatross fields are located in the ENEWSW oriented Hammerfest Sedimentary Basin, itself located in the SW Barents Sea, about $130 \mathrm{~km}$ off the coast of Norway (Fig. 1). Moreover, at Snøhvit, $\mathrm{CO}_{2}$ is being stored underground in a saline aquifer below the hydrocarbon reservoir.

In the Lower Jurassic, the Tubåen Formation (Fig. 2) contains thick sandstone bodies with thin shale beds indicating an estuary as a depositional environment [45]. It has moderate reservoir quality due to a higher amount of shale content and intermediate value of net-to-gross ratio [57]. The middle Jurassic St $\varnothing$ Formation (Fig. 2) is the main reservoir rock in the Hammerfest Basin, consisting of vertically stacked units of the lower to the upper beach slope deposits [86].

Potential source rocks in the area include the Triassic shales of the Ingøydjupet Group (Fig. 2) [45]. A regional transgression event in the (Lower Jurassic) period led to the deposition of basic marine tidal flats and coastal plain deposits associated with the Nordmela Formation, (Fig. 2) [45]. The Nordmela Formation is a source rock and mainly located in the area NW of Snøhvit [45].

From the (Middle to Upper Jurassic) period, there was a development of organic-rich fine-grained rocks over large areas of the Barents Sea, such as those of the Hekkingen Formation, (Fig. 2). The Hekkingen Formation (Fig. 2), constituted of very dense lithologies, is considered the tightest formation, which could thus act as a seal (Fig. 4). This important rock has furthermore an excellent source rock potential $[45,55]$. Thus the Hekkingen Formation represents both source and cap rock.

\section{Barents Sea glaciation history}

The Lower Cretaceous is characterized by an uplift of structural highs, a fault reactivation during the (Hauterivian-Barremian) of the E-W trending normal faults initially formed by Kimmeridgian tectonics, and a NS trending fault activity during the (Aptian) [18, 19, 58]. The western margin of the Barents Sea, including the Hammerfest Basin, subsided, tilted and was affected by a significant a TWT thickness Hekkingen Fm (seal)

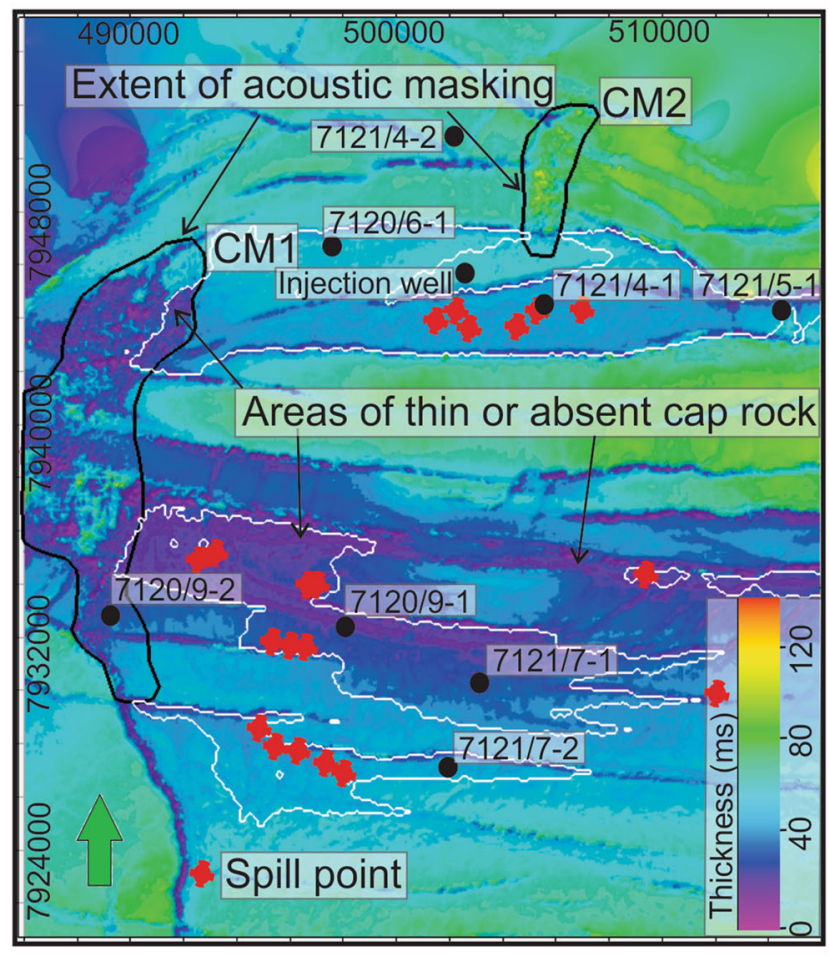

Fig. 4 a The figure illustrates the spatial relationship between the reservoirs, spill points and cap rock distribution through a thickness map of the Hekkingen Formation and the gas chimneys. b The figure corresponds to an RMS amplitude map at $-720 \mathrm{~ms}$ depth. The acoustic masking is defined at the Top Fuglen level (black line) in

\section{b RMS amplitude slice at $720 \mathrm{~ms}$}

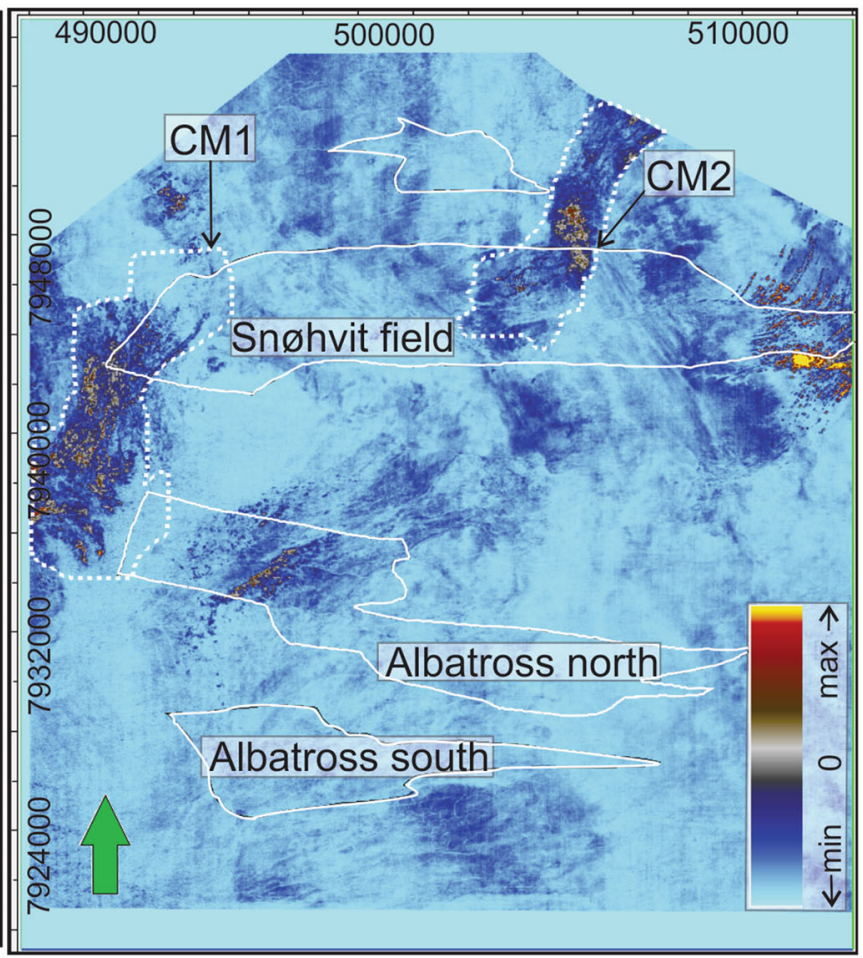

$\mathbf{a}$ and at the Top Torsk Formation level in b. Black line in a and white interrupted lines in $\mathbf{b}$ indicate the extent of the gas chimney at the Top Fuglen level in a and at the Torsk Formation level (white dashed line) in b. Continuous white lines outline the main reservoir units 
reactivation of faulting during the Upper Cretaceous-Paleogene, dominated by shear movements and regional transforming faults [18, 33]. The Cenomanian-Campanian interval has been affected by numerous layer-bound polygonal faults of the Nygrunnen group [2, 9, 59].

The Neogene is characterized by compression and shelf uplift, followed by the onset of multiple glaciations that took place in the Barents Sea [42, 80, 84]. During 2.4-1.0 Ma, ice sheets located in the northern Barents Sea expand southwards, and during the Middle Pleistocene eight full scale glaciations occurred [34, 36, 40, 83]. The last glacial maximum in the SW Barents Sea occurred in two stages, one advance took place prior to $22 \mathrm{ka}$ $[34,41,85]$ and the onset of the second one is estimated at around $15 \mathrm{ka}$ [42]. These glaciations affected the SW Barents Sea and led to considerable uplift, associated with erosion and isostatic rebound from deglaciation [65].

Glaciations removed thick layers of sediment from the seabed. More precisely, glacial unloading, which corresponds to the removal of great weights of rock or ice lying on the surface, due to deglaciation, that is to say ice melting, and erosion of underlying rocks, led to the reactivation and opening of many preexisting faults and creation of fluid flow pathways [53]. It also led to vertical migration of hydrocarbons from deep-seated source rocks [28, 68]. These source rocks are affected in a different way during uplift and normally stop generation of hydrocarbons. Hydrocarbons in the reservoir, on the other hand, migrate out of the reservoirs.

\section{Data and methods}

A conventional 3D seismic dataset (ST0306), covering the Snøhvit and Albatross reservoirs (Fig. 1), was acquired in 2003 by PGS Geophysical on request by Statoil ASA and was used in this study.

ST0306 dataset comprises a total area of 52,493 line kilometres. The survey was acquired with ten streamers and two Bolt Airguns. Each streamer contained 288 channels towed at $7 \pm 1 \mathrm{~m}$ depth. The group interval was $12.5 \mathrm{~m}$ and streamer separation was $100 \mathrm{~m}$. The shot point interval was $18.75 \mathrm{~m}$. The sources were towed at five metres depth with $50 \mathrm{~m}$ spacing. Operation pressure was $3090 \mathrm{in}^{3}$. The signal had a recording length of five seconds and a sampling rate of two milliseconds. The recording frequency was set to be $>3 \mathrm{~Hz}$ and $<206 \mathrm{~Hz}$.

The dataset has been processed by CGG Norge to zero phase and with a frequency filter varying with depth. A high pass filter of 5-20 Hz was applied for the first $600 \mathrm{~ms}$ below the seafloor. The low pass filter is varying with depth: $500 \mathrm{~ms}$ bsf. 70-80 Hz, $1500 \mathrm{~ms}$ bsf. 65-75 Hz and $2500 \mathrm{~ms}$ bsf. 60-70 Hz.

Seismic interpretation methods were applied, reflections were interpreted and time based and attribute maps, using various Petrel based methods, were produced. More precisely, "autotrack" was the tool used that allowed the interpreter to pick a seismic event accurately along a seismic line.

Volume-based attributes were used, such as RMS amplitude to measure the reflectivity within a time window, for detecting amplitude variations and for bright spot detection. The RMS seismic amplitude highlights the high amplitude anomalies within a volume by extracting the square root of the sum of squared amplitudes within a volume and dividing it by the number of squared amplitudes.

The variance attribute was used (edge method) to discriminate between low and high continuity of seismic reflections and to display incoherent areas with high contrast. It is also useful for visualizing faults, other zones of seismic disturbance, such as fracture swarms, and in general it detects zones with sharp edges or discontinuities, such as gas chimneys [7]. The variance cube is found under Application Manager-Seismic. The cube is generated from a predefined volume limited by inlines, crosslines and time values. The attribute is created by finding trace-to-trace differences in the volume. To display more than inlines, crosslines and time slices have to be generated.

Well log data from wells located in the vicinity of the seismic cube ST0306 were integrated into the interpretation, which helped to gain understanding of the lithology, fluid content and geological and physical properties of the subsurface. Particularly, the well tops information was important for a well-to-seismic tie to identify and delineate the stratigraphy in the study area (Fig. 2).

At Snøhvit, well 7121/4-1 targeted the reservoir and the oil-water contact (OWC) (Figs. 1c, 2a). Other wells that were used in the study include well 7121/4-2, 7120/5-1, 7120/6-1, 7120/12-1, 7121/5-1 and 7121/7-1.

\section{Description of how the structural spill points were calculated and mapped}

Structural spill points were identified (Fig. 3a, b, f, g), corresponding to the shallowest opening of the trap, by initially mapping the trap, corresponding to the bottom of the Hekkingen Formation (or top of the Fuglen Formation), and subsequently identifying the points which are the shallowest. At Snøhvit, the extent of the Top Fuglen Formation above the gas-oil contact (GOC), [above $2403 \mathrm{~m}$ below mean sea level (MSL)], and at Albatross above the gas-water contact (GWC), (above $1880 \mathrm{~m}$ below MSL), allowed us to obtain the geometry of the structural trap by cutting off the Top Fuglen Formation surface at the abovementioned GOC and GWC values, respectively (Fig. 3). Once the geometry of the trap is determined, either a $2 \mathrm{~m}$ or a $1 \mathrm{~m}$ interval from the bottom of the trap was extracted, just above the GOC and GWC, to obtain the locations of 
the spill points. Figure 5 illustrates the points corresponding to the $2 \mathrm{~m}$ interval (from 2403 to $2401 \mathrm{~m}$ at Snøhvit and 1880 to $1878 \mathrm{~m}$ at Albatross) and $1 \mathrm{~m}$ interval (from 2403 to $2402 \mathrm{~m}$ and 1880 to $1879 \mathrm{~m}$, respectively) above the shallowest opening of the trap. There are obviously more spill points when a $2 \mathrm{~m}$ interval is applied. Although the seismic data does not resolve such small thicknesses, using a 1 and $2 \mathrm{~m}$ interval is still useful for locating the spill points geographically.

\section{Results}

\section{Stratigraphic and structural interpretation}

Reflections associated with the main geological formations were identified using well log data from NPD $(2008 ; 2011)$ (Fig. 2). The seismic interpretation focused on the strata from the seabed down to the Top Snadd reflection including the URU, which corresponds to an angular regional unconformity which separates dipping well-bedded preglacial sedimentary rocks of Tertiary age and older from the upper, sub-horizontal layers of glacigenic sediments (Fig. 2) [38, 75]. The glacial sediments above the URU make up only up to $100 \mathrm{~ms}$ TWT of horizontally layered strata in this area as the uppermost reflectors of this unit are cut by erosion. Sedimentary strata in the upper part of the Torsk Formation dip towards the SW and are interpreted as a large-scale clinoform system (Fig. 3a, b, d, g). Several of the clinoforms show increased seismic amplitudes, particularly in the upper part of the stratigraphy (Fig. 3a, b, d). Some of these high amplitudes occur over or close to areas characterized by chaotic low-amplitude seismic data (Fig. 3).

Faults that terminate in the Upper Jurassic in the study area are referred to as, "Jurassic faults" in the text. Faults with offsets into the Cretaceous or that are active until the Cretaceous are entitled "Cretaceous faults" and in the same way faults that are active until the Tertiary, "Tertiary Faults". Only a few faults are visible at the top of the Torsk Formation, indicating that they were active into the Tertiary (Fig. 3a-c, f, g).

Formation tops corresponding to the Kviting Formation and the Intra Kviting, the Kolje Formation, the Knurr Formation and the Hekkingen Formation were also interpreted (Fig. 2). The Top Hekkingen surface is a strong reflector with medium to high amplitude and high frequency (Figs. 2a, 3c-h) that can easily be followed throughout the study area. The Hekkingen Formation is often affected by acoustic masking, which is most a

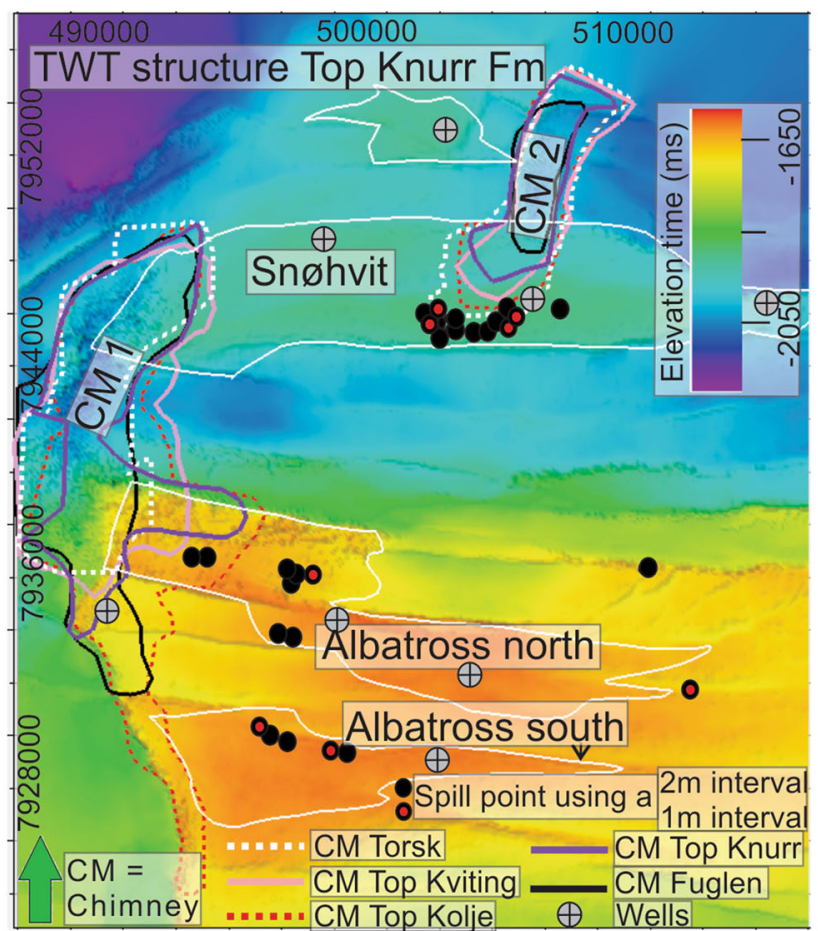

Fig. 5 a The figure shows gas chimney variability with depth, on a time structure map at the top of the Knurr Formation, for both CM1 and CM2. Spill point location using a $2 \mathrm{~m}$ interval and a $1 \mathrm{~m}$ interval are also shown, $\mathbf{b}$ the figure illustrates a well section at well 7121/4-1. b

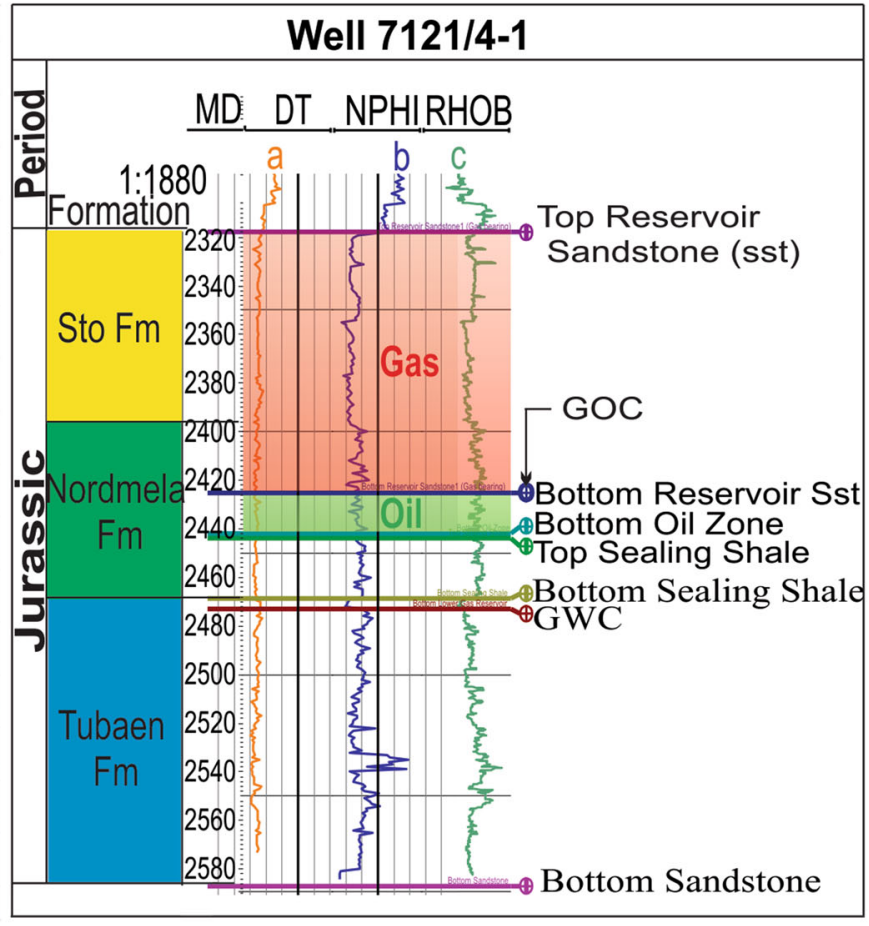

Common logs extent: for log a (DT) from 49.35 to $215.51 \mu \mathrm{s} / \mathrm{ft}$, for $\log \mathrm{b}$ (NPHI) from -0.0418 to $0.5308 \mathrm{~m}^{3} / \mathrm{m}^{3}$ and for $\log \mathrm{c}$ (RHOB) from 1.6498 to $2.9810 \mathrm{~g} / \mathrm{cm}^{3}$ (for location of $\mathbf{b}$, see Fig. 1c) 
pronounced around the Jurassic faults (Fig. 3d, e, h). The Kviting Formation is characterized by small scale faulting, most pronounced in areas not affected by acoustic masking (Figs. 2a, 3f, g, h). There are also faults in masked areas but in areas with no masking, we can see the faults more easily. The Top Knurr reflector is characterized by a low to medium amplitude and frequency where as the Top Kolje reflector by a medium to high amplitude, low to high frequency and medium to high continuity (Figs. 2a, 3c-h).

Most of these formations have been affected by faulting with Cretaceous and Tertiary faults having an offset varying from $50-300 \mathrm{~ms},(63-381 \mathrm{~m}$, using a conversion of $1 \mathrm{~ms}$ two-way time $=1.27 \mathrm{~m}$ ), but typically between 100-200 ms (127-254 m) (Fig. 3a-c, e). Fault throws vary from $20-135 \mathrm{~ms}(25-171 \mathrm{~m})$ at the top of the Knurr Formation (Figs. 2, 3), for example, with the fault offset gradually decreasing through the increasingly younger sequences (Fig. 3).

The Hekkingen Formation source rock/cap rock layer, just above the Fuglen Formation, is characterized by a strong reflection amplitude at its top with negative (reversed with respect to the seafloor) polarity, represented by blue colours. The reflection associated with the Top Fuglen Formation is characterized, however, by positive reflection amplitude, represented by red colours (Figs. 2, 3). The interval between the Top Hekkingen and Top Fuglen reflections shows low seismic amplitudes and discontinuous reflections reinforcing the idea that the Hekkingen Formation corresponds to a source rock that generated significant quantities of hydrocarbons in the area. Jurassic faults (Figs. 2, 3a, b, d, e) display a vertical displacement at the level of the Fuglen Formation varying between 20 and $150 \mathrm{~ms}$ (Fig. 3a, b, d, e). An offset of approximately $100 \mathrm{~ms}$ corresponds to a throw of $150 \mathrm{~m}$, if a velocity of $3000 \mathrm{~m} / \mathrm{s}$ based on well $\log$ data is assumed.

The Hekkingen Formation (Figs. 2, 4) shows variable thickness across the graben-horst structures most pronounced from the graben towards the horst formation. The thickness of the Hekkingen Formation varies between $40-60 \mathrm{~ms}$ (60 and $90 \mathrm{~m}$, assuming $V \mathrm{p}=3000 \mathrm{~m} / \mathrm{s}$, from well $\operatorname{logs}$ at reservoir level) above the horsts and between $80-100 \mathrm{~ms}(120-150 \mathrm{~m})$ above the grabens (Fig. 4). The thickness of the interval between the Top Fuglen Formation and Top Hekkingen Formation decreases towards the faults on the horsts and increases towards the fault area in graben structures (Fig. 4).

Places, where the Hekkingen Formation is at its thinnest $(<10 \mathrm{~ms})$ often coincide with areas of chaotic low-amplitude seismic (Figs. 3h, 4). The Hekkingen Formation is often found to be thinner at the structural highs of the Snøhvit area, corresponding to the horst structures characterising the Snøhvit and Albatross reservoirs (Fig. 4). In the area where the chaotic low-amplitude seismic coincides with the northern block of the horst limiting the Snøhvit reservoir, the Hekkingen cap rock is about $105 \mathrm{~m}(70 \mathrm{~ms})$ thick (Fig. 4).

\section{Reservoirs}

The Top Fuglen reflection defines the top of the reservoir. The St $\varnothing$ Formation, Nordmela Formation and Tubåen Formation correspond to the reservoir intervals (Figs. 2, $5 b)$. The location of these hydrocarbon bearing formations as well as the GOC and GWC (Figs. 3f, g, 5b) suggests that the Stø Formation and the Nordmela Formation are the main gas- and oil-bearing reservoirs, whereas the Tubåen Formation has reservoir quality only in certain locations [49]. $\mathrm{CO}_{2}$ has been injected into the Tubån Formation, another important reservoir, as well as the lower parts of the Stø Formation (Figs. 2, 5b) [13, 17, 72]. The transition from the Tubån Formation to the Nordmela Formation is characterized by a rise in bulk density and a decrease in sonic velocity (Fig. 5b) and from the Nordmela Formation to the Stø Formation by a decrease of both neutron porosity and bulk density (Fig. 5b). However, this could also be due to a possible gas effect.

\section{Fluid contacts}

The top of the reservoir sandstone at Snøhvit, which is gas filled, is at $2296 \mathrm{~m}$ below MSL (all depths are derived from the Statoil well completion reports) in well 7121/4-1, (Fig. 5b). The GOC is observed at $2403 \mathrm{~m}$ below MSL in well 7121/4-1 (Figs. 3a, g, 5b). Sealing shale then separates the upper gas-oil system from a lower gas reservoir (Fig. 5b). This lower gas reservoir starts at $2446.5 \mathrm{~m}$ below MSL and the GWC is at $2451 \mathrm{~m}$ below MSL in the 7121/41 well (Fig. 5b). This zone continues down to $2565 \mathrm{~m}$ below MSL. The thickness of the top gas bearing zone varies laterally from $107 \mathrm{~m}$ at well 7121/4-1 to about $50 \mathrm{~m}$ in the intermediate wells $7121 / 4-2$ and $7120 / 6-1$ and reaches about $60 \mathrm{~m}$ in well 7121/5-1. In well 7121/4-2, the main gas zone consists of an interbedded sandstone/shale sequence. In the Albatross area, from well 7121/7-1, the reservoir sandstone of (Middle Jurassic) age and dry gas bearing, begins at $1826.5 \mathrm{~m}$ below MSL and ends at the GWC at $1880.5 \mathrm{~m}$ below MSL (Fig. 3a, f).

\section{Indications for fluid flow}

\section{Vertical fluid flow features}

Chaotic low-amplitude seismic zones (CM1 and CM2)

There are two large gas chimneys in the data: one at the western edge of the study area hereafter referred to as gas 

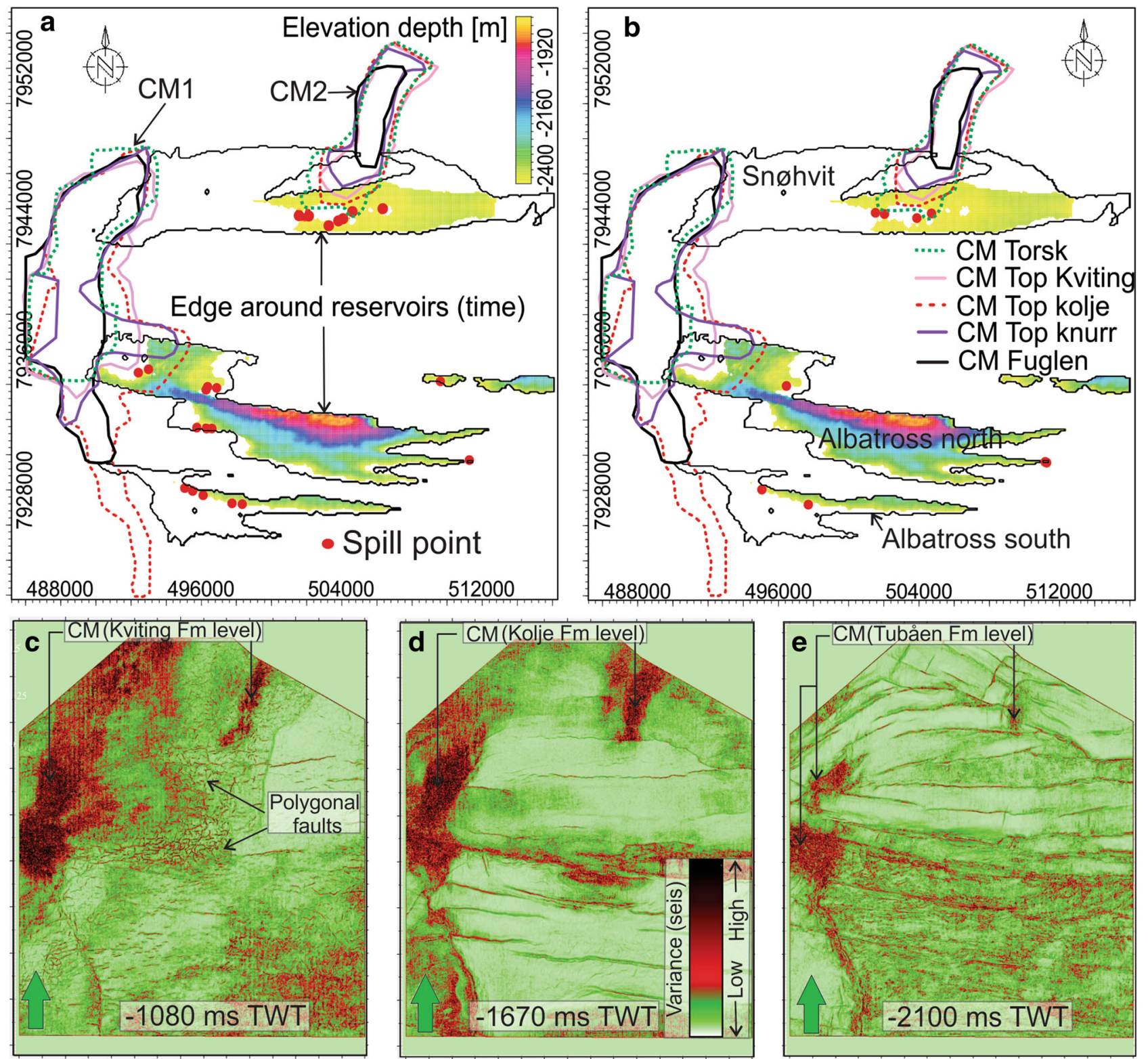

Fig. 6 The figure shows gas chimney variability with depth for both CM1 and CM2 and spill point location using a a 2 m interval, b a $1 \mathrm{~m}$ interval. The following figures correspond to variance maps at

chimney 1 (CM1) (Fig. 3a, b, e, h), and another at the northern edge of the Snøhvit field, referred to as gas chimney 2 (CM2) (Figs. 2, 3a, b). These areas of chaotic low-amplitude seismic, appearing as two separate columnar zones (CM1 and CM2), are characterized by a variable extent of up to $100 \mathrm{~km}^{2}$ (Figs. 3a, b, e, h, 4). The upper termination of the chaotic low-amplitude seismic zones is characterized by stronger reflections than in the surrounding sediments, related to a greater acoustic impedance contrast. These high amplitude anomaly reflections also show reversed polarity compared to the seafloor reflection and occur in the Upper Torsk Formation. Both CM1 and c $-1080 \mathrm{~ms}$ depth (Kviting Formation) d $-1670 \mathrm{~ms}$ (Kolje Formation) and e at $-2100 \mathrm{~ms}$ (Tubåen Formation)

CM2 have an elongated shape in plan view (Figs. 5a, 6) and extend laterally to reach up to $6 \mathrm{~km}$ in width and $13 \mathrm{~km}$ in length (Figs. 5a, 6). The extent of the acoustic masking zone, beneath the enhanced reflections, that belongs to CM1 or CM2 varies with depth (Figs. 2a, 3a, e, $\mathrm{h}, 4,5 \mathrm{a}, 6)$. The acoustic masking area varies from approximately 60 to 97 to $71 \mathrm{~km}^{2}$ for CM1 and from approximately 20 to 23 to $10 \mathrm{~km}^{2}$ for CM2 at the Torsk, Kolmule and Fuglen-Kolje intervals, respectively.

These large, columnar features have been interpreted as chimneys, seismic expressions for the vertical flow of fluids through subsurface sediments [46, 59, 82]. Gas 
accumulations occur at the top of these chimneys resulting in the observed high amplitude anomalies. In addition, low frequency content at the level of the Kviting Formation may indicate the presence of free gas (Fig. 3e, h) due to attenuation of higher frequencies. Gas-bearing sediments absorb more seismic energy than water-bearing intervals. In addition, the presence of gas within the pore space dramatically alters the mesoscopic fluid flow [30, 63], which has a major influence on the attenuation of seismic waves [52]. More specifically, free gas causes compressional wave attenuation and strongly scatters the acoustic energy of a high frequency signal.

Generally, the shallow high amplitude anomalies acoustically mask the area beneath and do not reveal the origin of these features. The most severe masking is seen at the Albatross horst structure (Fig. 3a, h) and the lateral extent of such masking areas varies with depth (Figs. 5a, $6)$. The boundary of the chimneys coincides with or is located close to the location of the spill points of the reservoir zone, see previous sections indicating that they might be related (Figs. 3a, f, g, 5a, 6).

When superposing the extent of gas chimneys with spill point locations (Figs. 4a, 5a, 6a, b), we observe that spill points of the Snøhvit reservoir coincide with the southernmost boundary of CM2 (Figs. 5a, c, 6a, b). Likewise, CM1 coincides with spill points of the Albatross field and areas of thin caprock at the westernmost part of the Snøhvit field (Figs. 4a, 5a, 6a, b).

In the Torsk Formation, the extension of the high amplitude anomaly at the upper termination of CM1, is limited at $\sim 750 \mathrm{~ms}$ (Fig. 3a, e, h) and between 625 and $725 \mathrm{~ms}$ TWT depth for CM2 (Fig. 3i). In CM1, the faults cutting through the Cretaceous sequence contain laterally the gas chimney (Fig. 3a, h). Reflections of the Top Kviting and Fuglen Formations provide evidence for a push down effect, of up to $35 \mathrm{~ms}$ on dimmed reflections in CM2, indicating the presence of a low velocity material that may be related to the presence of gas within the chimneys (Fig. 3a, i).

CM1 is bound by two E-W trending major faults active into the Tertiary (Figs. 3a, b, e, h, 5b, c, 6) and is located in areas where the Hekkingen Formation is thin or absent (Fig. 4). The southern and northwestern parts of CM1 are also affected by faults whose activity was limited to the Jurassic. South of CM1 a major NW-SE trending fault, associated with smaller faults characterized by a trend perpendicular to that of the major one, is observed (Fig. 3a, b). At the Albatross field, the westernmost spill points are located within the extent of CM1 at the Top Kolje Formation level (Fig. 6a, d).

Gas chimney CM2 is located in the northeastern part of the study area (Figs. 2, 3a, b, i, 4, 5a, c, 6). It lies at the northernmost fault delineating the Snøhvit reservoir
(Fig. 4). Specifically at the Torsk Formation and Kolje Formation levels (Figs. 3i, 4c, 6a, b), the area of acoustic masking in CM2 is observed further westward and southward than at other levels. Low frequency shadows are seen directly below this high amplitude anomaly within the Torsk Formation and around the Kviting and Fuglen reflections, attesting the presence of a gas chimney here, namely CM2 (Fig. 3i). The southern boundary of CM2 coincides with the spill points of the Snøhvit reservoir (Figs. 5a, 6).

\section{Shallow gas accumulations}

High amplitude reflections are present in both the glacial sediments at the URU and the underlying Upper Torsk Formation. These high amplitudes are interpreted as sedimentary layers, containing shallow gas accumulations. They generally dip towards the west (Fig. 3a, d, g, h, i). High amplitude reflections are also identified at intraglacial level, above the URU, regionally [39, 41, 62, 65, 82] and along the western flank of the Veslemøy High [9].

The Tertiary Torsk Formation above the Snøhvit and Albatross gas fields is characterized by numerous high amplitude bright spots and enhanced reflections (Figs. 3ac, f, h, 4). High amplitude anomalies and phase reversals along the URU reflection and in the Pliocene-Pleistocene Nordland Group are also observed (Figs. 2, 3a-c, e-g). They appear very often in the form of vertically stacked amplitude anomalies (Fig. 2 top northern side, $500 \mathrm{~m}$ in extent, top of Fig. 3c measuring $1 \mathrm{~km}$ wide and southern side of Fig. 3e of $700 \mathrm{~m}$ ). The acoustic masking and the bright spots of limited lateral extent that have been observed around the masked areas, e.g. at the level of the Kviting Formation (Figs. 5a, 6c), and in the lower parts of the Torsk Formation (Figs. 3a, e, i) can be interpreted as a presence of shallow gas accumulations in the system [4].

The Nordland Group is a more impermeable unit consisting of compacted glacial sediment and often reveals high amplitude anomalies beneath and within the glacial units (Figs. 2, 3a-c, f, g). In some places, these anomalies seem to follow glacial NW-SE lineations within the URU reflection. The URU reflection, above the bright spot corresponding to the top of CM1 (Fig. 3a, h), is characterized by a "faulted" horizon geometry. This observation, as well as the observed pattern of these, sometimes isolated, occurrences of gas within the Pliocene-Pleistocene Nordland Group, might suggest updip and lateral migration of fluids via the inclined faults at the URU level and further lateral flow within this sequence (Figs. 2, 3a-c, f, g, i).

In some locations below the URU, possible gas accumulations are observed. They are found above major faults that were active into the Tertiary (Fig. 3a-c, e-g). This might indicate that faults may have acted as pathways for 
fluid migration. The faults connect with the reservoir zone and are located near the spill points of both the Snøhvit and Albatross reservoirs mapped in previous sections (Fig. 3f, g). For a detailed description of how we assessed, calculated and mapped the structural spill points, see section on data and methods above.

\section{Discussion}

We have seen how large vertical fluid flow features occur at the spill point of hydrocarbon reservoirs. This observation together with the presence of seismic amplitude anomalies above large faults suggests a role for these geological features as possible important pathways for fluid migration. The discussion focusses on the relationship of fluid flow to subsurface stratigraphy and structure, and suggests a model for the origin of the fluid migration into the shallow subsurface.

\section{Fluid flow features}

Increased amplitudes are seen at fault planes, accompanied with low frequencies (Fig. 3a, h), especially in the Upper Cretaceous Kolmule Formation (Fig. 3a, e) and at the top of the fault in the Torsk Formation (Fig. 3a, c, e-g). Some of the high amplitude anomalies are bounded by the E-W trending faults (Figs. 2, 3a, b, e, f, h). These observations suggest that some faults act as pathways for fluid in the shallow subsurface or have done so in the past, which is in accordance with observations by [82] and by [58].

Numerous high amplitude anomalies in the shallow subsurface represent shallow gas accumulations at several levels, but most notably at URU. Amplitude anomalies above the large chimneys also crosscut lithological reflections in various parts and mimic the seafloor, indicating possible occurrence of gas hydrates (Fig. 3a, h) [58, 59].

Regionally, patchy high amplitude anomalies occur also at unit boundaries of the (Plio-Pleistocene) succession on the western flank of the Veslemøy High [9]. The combination of high amplitudes, bright spots and low frequencies point towards fluid migration and/or fluid accumulation zones. Acoustic anomalies present along the URU provide evidence that implies that gas has accumulated in the upper parts of the overburden, (Figs. 2, 3a-c, e-g). Reflection energy varies laterally along the URU with occasional phase reversals and with the highest reflection amplitudes in areas associated to acoustic masking (Figs. 2, 3a, b, e).

Gas chimney width varies with depth (Figs. 3a, b, h, 4, $5 a-c, 6)$. This variability in size of the gas chimneys is also observed in the Loppa high area [64]. In CM1, for example, the initial high variability in gas chimney width between the Fuglen Formation and Kolje Formation levels is followed by a gradual decrease in width up to the Torsk Formation level (Figs. 5a, 6). This is due to the association of Jurassic and Cretaceous faults near the gas chimney (Fig. 3a, h) controlling and guiding the direction of fluid flow.

In CM2, there is a gradual increase in the size of the gas chimney up to the Kolje Formation level (Fig. 6d), where the gas chimney reaches a total circumference of $24.94 \mathrm{~km}$. Then follows a slight decrease in the size before it reaches its maximum extent at the Torsk Formation level (Figs. 5a, c, 6), where it reaches a maximum circumference of $28.62 \mathrm{~km}$. In this case, as fluid migrates upwards it expands, except at the level of the Kviting Formation where the gas chimney reduces in width to reach a circumference of $23.66 \mathrm{~km}$ (Figs. 5a, 6a, c). This is probably due to the increased permeability of the sandstones contained in this formation compared to the underlying shaledominated strata of lower permeability. The sandstones can accommodate more fluid in their pore space which is high here, as shown by the sharp increase in the neutron porosity log curve from well 7120/12-1 [86], which in turn leads to a narrowing of the gas chimney. The variation in the width of the gas chimneys can also be explained in terms of the mechanical contrast that exists between the shale and sandstone. Shales are mechanically softer than sandstone and they therefore react differently to stress; a stress that in this case results from the pressure the gas exerted on the host rock.

The distinct shape of the gas chimneys (i.e. narrowest at base and top) probably indicates active gas seepage or gas remaining in the sediment. It most probably does not correspond to just a shadowing effect from the high amplitude anomalies at the top of CM1 and CM2. Pure shadowing would tend to decrease in width with depth due to undershooting.

\section{Origin of large gas chimneys at Snøhvit}

Fluid flow can take place via several different migration mechanisms in consolidated sediments, such as by fracture flow [67], Darcy flow and diffusion (Fig. 7) [7, 35].

Fluid migration processes start once the gas is no longer trapped beneath the seal, possibly due to an increase in pore pressure associated with sediment compaction that may lead to vertical fracturing and the ensuing formation of cracking pipes by which fluids are focused vertically through the overburden [7, 47].

The Hekkingen Formation (Fig. 2) could act as a seal (Fig. 4) but at the same time, there are indications that fluids may have bypassed this seal in the Snøhvit area, leading to the formation of gas chimneys. The total or partial absence of cap rock in certain areas (Fig. 4) and the existence of spill points in the trap near faults or on the 

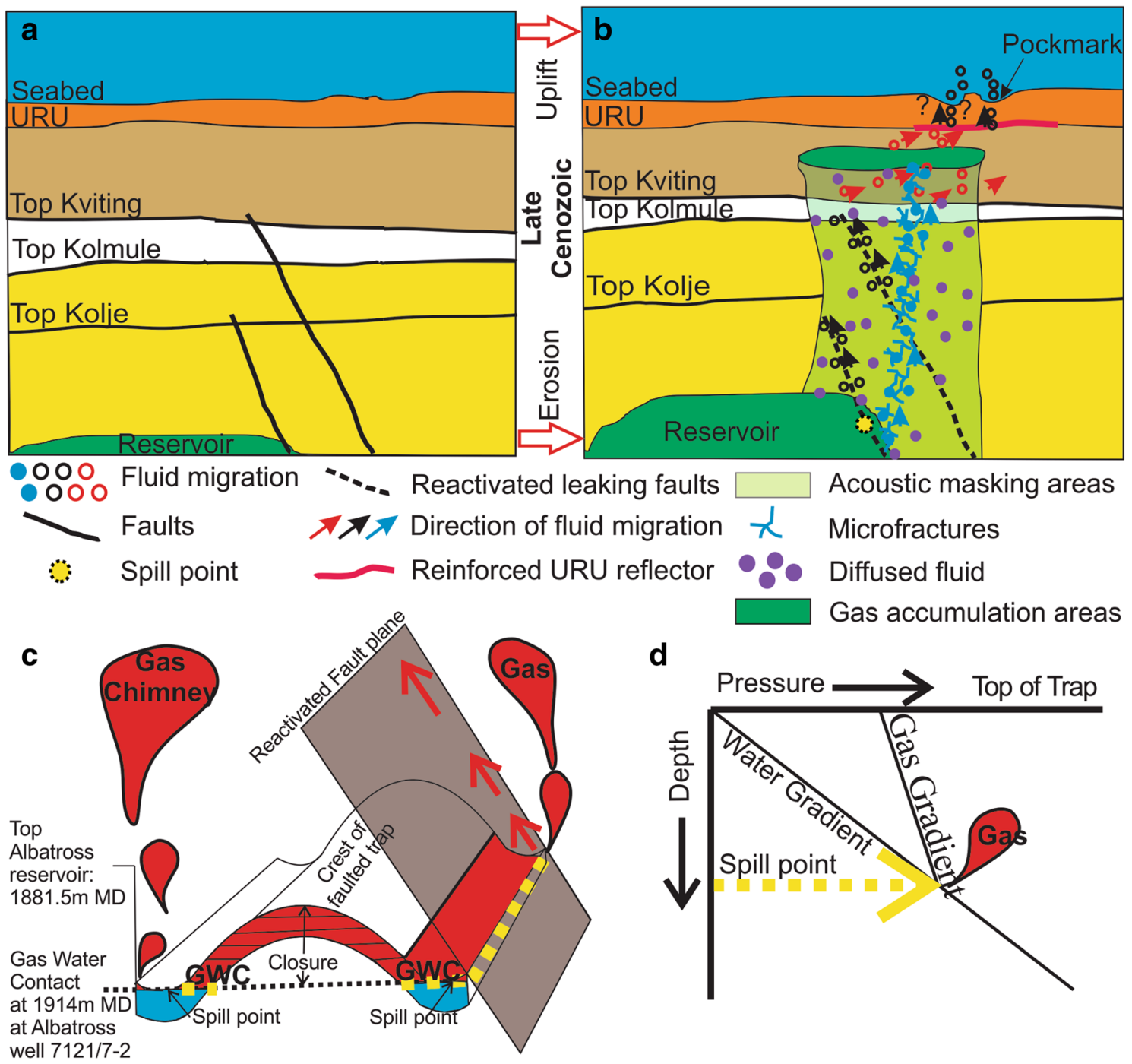

Fig. 7 The figure illustrates a model of fluid migration along gas chimneys and faults a before denudation and $\mathbf{b}$ after denudation, following a Late Cenozoic phase of uplift and erosion. c The figure illustrates a chimney formation mechanism through escape at

faults (Figs. 3a, f, g, 5a, 6), suggests that fluid has bypassed through the seal. Moreover, high resistivity measurements have been observed in various logs in the Hekkingen Formation (Fig. 5b). These logs increase when entering the reservoir structures, as resistivity is normally higher in hydrocarbons than in water. In addition, the observation that faults have also been responsible for displacing the sealing lithologies (Figs. 3, 4), reinforces the assumption that fluids may have bypassed the seal.

Through the Lower Cenozoic time, the dominant compressional stress direction was NW-SE [23, 45]. Moreover, in well 7120/5-1, the maximum compressional horizontal stress azimuth is $135^{\circ} \mathrm{N}$. The maximum horizontal ("extensional") stress direction is perpendicular to this and strikes at $45^{\circ}$. The Snøhvit faults with a NW-SE fault the spill point and fluid flow along first order reactivated faults, modified figure from [70] and $\mathbf{d}$ the figure corresponds to a pressuredepth diagram explaining how gas can reach the spill point (modified Figure from http://www.beg.utexas.edu/agi/mod12/m12-step04.htm)

orientation have their normal to the fault oriented in the same direction as the extensional stress regime that strikes at $45^{\circ}$ (Fig. 3b). In general, faults that are oriented perpendicular to the horizontal extensional stress direction are most likely to fail in sealing due to the existence of the lowest normal stresses across these faults [44]. Therefore, faults with this NW-SE orientation will thus probably not be sealing as some leakage could have taken place vertically through these fault planes [45].

As pressure only exists in fluids, the concentration of pressure and any pressure increases taking place along the NW-SE oriented fault planes means that fluids are already there and can migrate vertically using a fluid flow pathway along this fault plane (Fig. 7c). Moreover, all gas chimneys and areas where seismic is affected by acoustic masking 
and leaked gas, develop in areas that contain faults of such NW-SE orientation (Fig. 3b). Fluid migration through these faults (Fig. 3a, b) could have taken place through micro fractures or molecular diffusion (Fig. 7). When sufficient micro fractures link up into a large slip surface then a large seismic event or earthquake can occur. Molecular diffusion, however, corresponds to the thermal motion of all (liquid or gas) particles at temperatures above absolute zero.

Fluid flow in the region is suggested to be a consequence of Cenozoic erosion and uplift [27]. Moreover, the repeated glacial cycles and ensuing differential geographic uplift, which caused tilting and spilling of various structural traps in the area (Figs. 4, 5a, 6), might have had an added effect $[16,54]$. Before denudation and during maximum burial, where pressure and temperature are the highest [54], hydrocarbon generation is at its maximum and reservoir filling occurs (Fig. 7a) [45]. Significant uplift and erosion of the Barents shelf occurred in the Eocene, when large amounts of sediment were deposited in the Hammerfest Basin coming from eroded areas further east [19]. Furthermore, removal of overburden during the OligoceneMiocene led to gas expansion [59]. Later on, glacial erosion and glaciotectonic processes during the Plio-Pleistocene remove much of the Cenozoic sediments in the Hammerfest Basin and result in a net uplift, related to erosion, of up to $1000 \mathrm{~m}$ in the Barents Sea [33, 54].

Depressurization of hydrocarbon reservoirs in the Snøhvit area, as a result of erosion, translates into gas expansion. As the gas column expands to a volume larger than the initial, this leads to a larger hydrocarbon column height and to the capillary failure of the cap rock resulting in hydrocarbon leakage from the reservoir.

The uplift and erosion of the Barents Sea shelf during the Paleocene-Eocene opening and shear of the Norwegian-Greenland Sea also resulted in differential subsidence and margin tilting [16]. Assuming that uplift did not take place uniformly throughout the area, the tilting of various structural traps in the area, together with the aforementioned gas volume expansion could have been responsible for some part of the hydrocarbon loss during the Cenozoic. This could have taken place through the process of fluid expulsion and lateral remigration at the spill point of the reservoir (Figs. 5a, 6, 7) [33, 87]. Furthermore, tilting could have also changed the migration pathways.

Tilting, together with basin subsidence, may have led even to a change of the size and the spill points of structural or stratigraphic traps throughout the geological time scale. Spill points are located in areas where the cap rock is thin, at Snøhvit, or absent, at Albatross (Figs. 4, 5a, 6). Fluid flow can take place through these spill points, if the trap is filled to spill, at the bottom of the closure corresponding to the GWC (Fig. 7c). The spill point thus corresponds to the point where the gas and water gradients meet at a certain depth.

\section{Model of formation for gas migration out of reservoirs at spill points}

We hypothesize that fluids may have thus migrated out of the traps at the spills points, leading to the emplacement and development of the gas chimneys in the area (Figs. 5a, 6). Erosion is responsible for the hydraulic fracturing of cap rocks and the consequent expulsion of fluids due to the expansion of gas reservoirs [16]. As the gas expanded [54], the gas lying close to the bubble point could have exsolved from the oil [54]. The expanding gas can reach the areas beneath the spill points and migrate out of the trap. Due to gas expansion, the gas-oil contact is driven down by increased gas volume. After gas expansion has reached a certain level, or the gas accumulation has reached a specific thickness, gas would accumulate in overpressured pockets and fracturing of the reservoir occurs. Any excess gas at the top becomes sufficient to force the gas through the seal. The seal ruptures or fails by injection of the trapped fluid or by hydrofracturing [8]. Seal failure would take place at the point corresponding to a structural high of the seal (Figs. 4, $5 a, 6)$ which is also the point where the overpressure is the highest.

Gas may migrate both vertically and laterally, which may also explain why there is an observed variability of the gas chimney extent with depth (Figs. 5a, 6). The upward migration of gas-rich fluids leads to gas accumulation in shallower areas, (Figs. 3, 4, 7), which is observed above and in close vicinity of the chimneys (Fig. 3a, e). The CM1 and CM2 gas chimneys terminate stratigraphically within the Torsk Formation suggesting that migration must have occurred after its deposition. However, fluid leakage has most likely ended since the present-day GWC, is situated above the spill points at $1902 \mathrm{~m} \mathrm{MD} \mathrm{(Fig.} \mathrm{3f),} \mathrm{and} \mathrm{since}$ tectonic activity has ceased.

\section{Gas migration along first order reactivated faults}

Fluid may also have migrated through faults and fractures (Fig. 3a, c, e-h). High amplitude anomalies above major faults cutting through Paleozoic formations and the reservoir, as well as deep-seated faults (Fig. 3a, c, e-g) suggests that these faults may have acted or still act as pathways for fluid migration.

Considerable volumes of deep thermogenic fluids have leaked from the Snøhvit Jurassic reservoir; indicated by the existence of a paleo gas-oil contact [59]. These thermogenic fluids migrate upwards through the gas chimneys and the first order reactivated faults, i.e. E-W $\left(85-90^{\circ} \mathrm{N}\right)$ trending extensional faults that bind the horst and graben 
structures in the study area into the Paleocene sediments [59]. A direct link between the Snøhvit reservoir structures and these first order faults exists, thus implying a possible root of leakage [59].

Erosion and uplift, leading to gas expansion and pressure increase, could have caused reactivation of large-scale fault systems such as those through the Lower Tertiary. This reactivation and increased breakup of the fault zones could in turn have led to fluid migrating through the first order reactivated faults (Fig. 7c). This dominant driving force could have led to the fracturing of otherwise impermeable rocks and migration of fluids [67, 73].

All heterogeneities in the crust like fractures, faults, and layering do accumulate stress. Stress changes induced by massive glacial erosion, however, could be large enough to reactivate some of these heterogeneities such as faults, due to the very rapid unloading of the crust. When fault reactivation takes place, it can lead to the mechanical fracture and brecciation of fault zones, thus creating secondary porosity. Both of these processes, brecciation and fracturing, can enhance porosity, permeability, and fluid migration pathways across fault zones and facilitate spilling from the reservoir [50].

Erosion is removal of sediments and can be regarded as unloading of the surface, which results in an increase of horizontal compressive stresses near and at the new surface [25, 81]. An increase in the compressive stress also results in a decrease of the sediments porosity and permeability in the subsurface. When the permeability is too low, the pore water can be inhibited from escaping, and this can lead to an increase in the pore pressure above the hydrostatic level, or in other words, to a significant overpressure. When the pore pressures reach values as high as the fracture gradient, which generally occurs in highly overpressured environments or at shallow depths, this can lead to the increase of cap rock permeability and a decrease in capillary entry pressures. This in turn can initiate hydrocarbon leakage from the reservoir and other fluid remigration. Under moderately overpressured conditions, however, the normal mode of failure is capillary failure [68].

In areas subject to rapid and massive erosion, related to compressive stress, the most likely site for fluid to migrate out of the reservoir would be through faults, rather than through hydrofractures breaking the seal [48]. Horizontal compressive stresses will not be favourable for the development or propagation of vertical hydrofractures. Hydrofractures, which in fact are extension fractures, develop in the orientation parallel to the maximum compressive stress and normal to the orientation of least compressive stress.

Spill points at the crossing points between faults and the GWC are observed (Figs. 3a, g, 7c), suggesting that fluid flow could have taken place at these specific locations (Fig. 7c).

The failure of deep-seated faults to effectively seal the trapped hydrocarbons has led to fluid reaching shallow strata such as the URU (Fig. 3a, c). These faults are reactivated, are younger than the Jurassic and Cretaceous ones and pass through the reservoir (Fig. 3a, c, e-g). In many places, small gas accumulations can be associated with the faults in the overlying sediments. Fluid flow may focus along faults initially and then might spread to overlying smaller faults and laterally into sedimentary layers, thereby reaching to shallow strata and possibly the seafloor (Fig. 3a, e-h) [58].

Other possible mechanisms causing stress changes that may in turn reactivate faults include those related to the load exerted by the ice sheet itself and to glacial isostasy. During glaciations, the ice sheet itself exerts a load on the surface, which results in stress changes in the shallower part of the crust. More importantly, glacial isostasy introduces flexural stresses, in the entire part of the elastic lithosphere. Both of the above-mentioned mechanisms may result in reactivation of faults [77].

When discussing about the initiation mechanisms involved in fluid migration and leakage, a strong focus is given on stress as it is the driving mechanism for fault slip and fracturing which provide the fluid pathways focused on here. In addition, a special focus is also given on tilting; both causing mechanisms, timing as well as the direction of tilting. Concerning tilting, we can propose the existence of two sub-mechanisms leading to tilting. This first one corresponds to an erosional process resulting in differential uplift. The second one is related to glacial isostasy, which introduces an additional uplift and isostatic tilt as a result of the thickness of the glacier during the glaciations. Regional tilting during the glaciations and the uplift phase results in changes to trap configuration and fluid migration deposits [20, 21].

Glacial loading and unloading cycles resulted in overpressure fluctuations in the subsurface reservoirs. During glacial loading, the increase of the pore pressures may lead to the compression of the gas phase and to the increase of the fluid density. The resulting inhibition of the capillary failure of the cap rock can also lead to hydrocarbon leakage from the reservoir [68].

Moreover, preglacial uplift could have generated significant overpressure in the Cenozoic strata due to western margin tilting [19]. More specifically, remigration of fluids, such as oil and gas, laterally over a large distance in the region can be due to time-transgressive differential tilting. As a result, petroleum was directed updip into proximal basin settings [55]. Such changes in structural attitude, or in other words tilting, as a result of uplift, can also create new potential hydrocarbon traps using structural 
culminations that were not closed in the past. It is important to note, however, that if the generation of hydrocarbons ceased after the uplift, such traps would be dry.

\section{Conclusions}

The study of 3D seismic data from the Snøhvit and Albatross reservoirs in the southwestern Barents Sea shows that large focused fluid flow structures occur in close vicinity to the major hydrocarbon reservoirs. Focused fluid flow occurred along the so-called gas chimneys and along faults that may have been reactivated. These two major pathways are associated with shallow gas accumulations, mainly within and beneath glacial sediments.

The main geological process facilitating the flow of fluids and the spillage from preuplift hydrocarbon accumulations is the Cenozoic exhumation of the Barents Sea, possibly combined with tilting of structural traps.

Mainly uplift caused an expansion of gas in hydrocarbon reservoirs allowing the gas to reach below the spill point. Fluid flow from these reservoirs then initiated at the spill points of the reservoirs, at the bottom of the closure corresponding to the GWC, which are located in areas where the cap rock is thin, at Snøhvit, or absent, at Albatross, and which coincide with the large gas chimneys observed in the Snøhvit area. Fluids may have thus escaped, through the spills points leading to the emplacement and development of the gas chimneys in the area.

A similar mechanism might also have led to migration of fluids along faults that were reactivated by glaciotectonic processes and that connect with spill points at reservoir depth. The stress changes due to glacial erosion may be large enough to cause reactivation of faults regardless of fault type. Indeed, any faults, whether they may be normal, reverse or strike-slip, close to the lateral ends of the reservoirs are thus likely to have been reactivated as a result of the glacial erosion in the Barents Sea [48]. We propose that the reactivation actually affects all faults with a higher likelihood for fluid migration taking place along the faults at the extremities of the reservoir. It should be noted, however, that the likelihood of reactivation also depends on other factors, such as on the magnitude of glacial erosion at the given location and the faults orientation to the stress field and other faults, among other.

Both gas chimneys and faults have allowed gas to migrate into shallow strata where it is trapped in shallow gas accumulations within the Torsk Formation, and mostly below the URU. The distribution of shallow gas accumulations indicates a somewhat more complex and lateral component of fluid migration in the shallower subsurface facilitated by smaller faults and along stratigraphic boundaries. Fluid migration may continue for a long time unless there are tectonic or rapid subsidence events that can put a halt to migration.

Acknowledgements We would like to thank the presubmission readers and the reviewers for their valuable advice and support. The research leading to these results has received funding from the European Union Seventh Framework Programme under grant agreement no. 265847 "Sub-seabed $\mathrm{CO}_{2}$ Storage: Impact on Marine Ecosystems $\left(\mathrm{ECO}_{2}\right)$ " and the Norwegian Research Council through the "Centre of Excellence for Arctic Gas Hydrates Environment and Climate (CAGE)". We are also thankful to Statoil for providing the seismic data used in this study. The University of Troms $\varnothing$ acknowledges the support of Schlumberger for the seismic interpretation software PETREL.

\section{References}

1. Andreassen K, Hogstad K, Berteussen KA (1990) Gas hydrate in the southern Barents Sea, indicated by a shallow seismic anomaly. First Break 8:235-245

2. Andreassen K, Nilssen EG, Odegaard CM (2007) Analysis of shallow gas and fluid migration within the Plio-Pleistocene sedimentary succession of the SW Barents Sea continental margin using 3D seismic data. Geo Mar Lett 27:155-171. doi:10.1007/ s00367-007-0071-5

3. Andresen KJ (2012) Fluid flow features in hydrocarbon plumbing systems: what do they tell us about the basin evolution? Mar Geol 332-334:89-108. doi:10.1016/j.margeo.2012.07.006

4. Badley ME (1985) Practical seismic interpretation international human resources development corporation. IHRDC Press, Boston, Miami

5. Berglund LT, Augustson J, Færseth R, Gjelberg JG, RambergMoe H (1986) The evolution of the Hammerfest Basin: habitat of hydrocarbons of the Norwegian Contintental Shelf. Nor Pet Soc Graham Trotman 1986:319-338

6. Berndt C (2005) Focused fluid flow in passive continental margins. Philos T Roy Soc A 363:2855-2871. doi:10.1098/rsta.2005. 1666

7. Cartwright J, Huuse M, Aplin A (2007) Seal bypass systems. Aapg Bull 91:1141-1166. doi:10.1306/04090705181

8. Cathles LM, Su Z, Chen DF (2010) The physics of gas chimney and pockmark formation, with implications for assessment of seafloor hazards and gas sequestration. Mar Petrol Geol 27:82-91

9. Chand S, Knies J, Baranwal S, Jensen H, Klug M (2014) Structural and stratigraphic controls on subsurface fluid flow at the Veslemøy High, SW Barents Sea. Mar Pet Geol 57:494-508

10. Chand S, Mienert J, Andreassen K, Knies J, Plassen L, Fotland B (2008) Gas hydrate stability zone modelling in areas of salt tectonics and pockmarks of the Barents Sea suggests an active hydrocarbon venting system. Mar Pet Geol 25:625-636

11. Chand S, Rise L, Ottesen D, Dolan MFJ, Bellec V, Boe R (2009) Pockmark-like depressions near the Goliat hydrocarbon field Barents Sea: Morphology and genesis. Mar Pet Geol 26:1035-1042. doi:10.1016/j.marpetgeo.2008.09.002

12. Chand $S$ et al (2012) Multiple episodes of fluid flow in the SW Barents Sea (Loppa High) evidenced by gas flares, pockmarks and gas hydrate accumulation. Earth Planet Sci Lett 331:305-314. doi:10.1016/j.eps1.2012.03.021

13. Chiaramonte A, White JA, Johnson S (2011) Preliminary geomechanical analysis of $\mathrm{CO} 2$ injection at Snøhvit, Norway. Am Rock Mech Assoc 11:1-9

14. Dando PR et al (1991) Ecology of a North-Sea Pockmark with an Active Methane Seep. Mar Ecol Prog Ser 70:49-63. doi:10.3354/ Meps070049 
15. Dore AG (1995) Barents Sea Geology, Petroleum Resources and Commercial Potential. Arctic 48:207-221

16. Dore AG, Jensen LN (1996) The impact of late Cenozoic uplift and erosion on hydrocarbon exploration: offshore Norway and some other uplifted basins. Global Planet Change 12:415-436

17. Eiken O, Gilding D, Hansen H, Nazarian B, Osdal B, Ringrose P (2013) Snøhvit: The history of injecting and storing $1 \mathrm{Mt}$ CO2 in the fluvial Tubåen Fm. Proc GHGT11

18. Faleide JI, Gudlaugsson ST, Jacquart G (1984) Evolution of the western Barents Sea. Mar Pet Geol 1(2):123-128

19. Faleide JI et al (2008) Structure and evolution of the continental margin off Norway and Barents Sea. Episodes 31:82-91

20. Fjeldskaar W (2000) An isostatic test of the hypothesis of ice-free mountain areas during the last glaciation. Norsk Geol Tidsskr 80:51-56. doi:10.1080/002919600750042672

21. Fjeldskaar W, Lindholm C, Dehls JF, Fjeldskaar I (2000) Postglacial uplift, neotectonics and seismicity in Fennoscandia. Quat Sci Rev 19:1413-1422. doi:10.1016/S0277-3791(00)00070-6

22. Gabrielsen RH, Færseth RB, Jensen LN, Kalheim JE, Riis F (1990) Structural elements of the Norwegian Continental Shelf. Part 1: the Barents Sea region Norwegian Petroleum Directorate. Bulletin 6:33p

23. Golke M, Brudy M (1996) Orientation of crustal stresses in the North Sea and Barents Sea inferred from borehole breakouts. Tectonophysics 266:25-32. doi:10.1016/S0040-1951(96)00181-3

24. Gudlaugsson ST, Faleide JI, Johansen SE, Breivik AJ (1998) Late Palaeozoic structural development of the South-western Barents Sea. Mar Pet Geol 15:73-102

25. Gudmundsson A (2011) Rock Fractures in Geological Processes. Cambridge University Press, Cambridge

26. Hansen J, Sato M, Ruedy R, Lacis A, Oinas V (2000) Global warming in the twenty-first century: an alternative scenario. P Natl Acad Sci USA 97:9875-9880. doi:10.1073/pnas.170278997

27. Henriksen E et al (2011) Uplift and erosion of the greater Barents Sea: impact on prospectivity and petroleum systems. Geol Soc Mem. doi:10.1144/M35.17

28. Henriksen E, Ryseth AE, Larssen GB, Heide T, Ronning K, Sollid K, Stoupakova AV (2011) Tectonostratigraphy of the greater Barents Sea: implications for petroleum systems. Geol Soc Mem. doi:10.1144/M35.10

29. Huuse M, Jackson CAL, Van Rensbergen P, Davies RJ, Flemings PB, Dixon RJ (2010) Subsurface sediment remobilization and fluid flow in sedimentary basins: an overview. Basin Res 22:342-360. doi:10.1111/j.1365-2117.2010.00488.x

30. Johnson BD, Boudreau BP, Gardiner BS, Maass R (2002) Mechanical response of sediments to bubble growth. Mar Geol 187:347-363. doi:10.1016/S0025-3227(02)00383-3

31. Judd AG, Hovland M (2007) Seabed Fluid Flow: The impact on Geology, Biology and the Marine Environment. Cambridge University Press, Cambridge

32. Karlsen DA, Skeie JE (2006) Petroleum migration, faults and overpressure, Part I: Calibrating basin modelling using petroleum in traps-a review. J Petrol Geol 29:227-255. doi:10.1111/j. 1747-5457.2006.00227.x

33. Kjemperud A, Fjeldskaar W (1992) Pleistocene glacial isostasy; implications for petroleum geology In: Brekke E, Larsen $\mathrm{H}$, Talleraas BT Norwegian Petroleum Society (NPF) Special Publication Larsen, E 1:187-195

34. Knies J et al (2009) The Plio-Pleistocene glaciation of the Barents Sea-Svalbard region: a new model based on revised chronostratigraphy. Quat Sci Rev 28:812-829. doi:10.1016/j.quascirev. 2008.12.002

35. Kroos BM, Leythauser D (1996) Molecular diffusion of light hydrocarbons in sedimentary rocks and its role in migrationa and dissipation of natural gas. Aapg Memoir 62:173-185
36. Laberg JS, Andreassen K, Knies J, Vorren TO, Winsborrow M (2010) Late Pliocene-Pleistocene development of the Barents Sea Ice Sheet. Geology 38:107-110. doi:10.1130/G30193.1

37. Laberg JS, Andreassen K, Knutsen SM (1998) Inferred gas hydrate on the Barents Sea shelf-a model for its formation and a volume estimate. Geo Mar Lett 18:26-33. doi:10.1007/ s003670050048

38. Laberg JS, Andreassen K, Vorren TO (2012) Late Cenozoic erosion of the high-latitude southwestern Barents Sea shelf revisited. Geol Soc Am Bull 124:77-88. doi:10.1130/B30340.1

39. Laberg JS, Vorren TO (1995) Late Weichselian Submarine Debris Flow Deposits on the Bear-Island-Trough-Mouth-Fan Marine. Geology 127:45-72. doi:10.1016/0025-3227(95)00055-4

40. Laberg JS, Vorren TO (1996) The Middle and Late Pleistocene evolution of the Bear Island Trough Mouth Fan. Global Planet Change 12:309-330. doi:10.1016/0921-8181(95)00026-7

41. Laberg JS, Vorren TO (2000) Flow behaviour of the submarine glacigenic debris flows on the Bear Island Trough Mouth Fan, western Barents Sea. Sedimentology 47:1105-1117. doi:10.1046/ j.1365-3091.2000.00343.x

42. Landvik JY et al (1998) The last glacial maximum of Svalbard and the Barents sea area: ice sheet extent and configuration. Quat Sci Rev 17:43-75

43. Larssen GB et al. (2002) Upper paleozoic lithostratigraphy of the southern Barents Sea Norwegian Petroleum Directorate Bulletin No. 9:76 pp, 63 figs., 71 tbl

44. Ligtenberg JH (2005) Detection of fluid migration pathways in seismic data: implications for fault seal analysis. Basin Res 17:141-153. doi:10.1111/j.1365-2117.2005.00258.x

45. Linjordet A, Grung-Olsen RG (1992) The Jurassic Snohvit GasField, Hammerfest Basin, Offshore Northern Norway. Aapg Memoir 54:349-370

46. Løseth H, Gading M, Wensaas L (2009) Hydrocarbon leakage interpreted on seismic data. Mar Pet Geol 26:1304-1319. doi:10. 1016/j.marpetgeo.2008.09.008

47. Løseth H, Wensaas L, Arntsen B, Hanken NM, Basire C, Graue K (2011) $1000 \mathrm{~m}$ long gas blow-out pipes. Mar Pet Geol 28:1047-1060. doi:10.1016/j.marpetgeo.2010.10.001

48. Løtveit IF, Gudmundsson A, Leknes L, Riis F, Fjeldskaar W (2009) Effects of glacial erosion on the state of stress and fluid pressure in petroleum reservoirs in the Barents Sea. Analytical and numerical studies on fluid reservoirs and fracture development in heterogeneous rocks $\mathrm{PhD}$ dissertation. University of Bergen, Bergen, Norway. ISBN 978-82-308-0828-3

49. Maldal T, Tappel IM (2004) CO2 underground storage for Snøhvit gas field development. Energy 29:1403-1411. doi:10. 1016/j.energy.2004.03.074

50. Mohammedyasin SM, Lippard SJ, Omosanya KO, Johansen SE, Harishidayat D (2016) Deep-seated faults and hydrocarbon leakage in the Snøhvit Gas Field, Hammerfest Basin, Southwestern Barents Sea. Mar Pet Geol 77:160-178. doi:10.1016/j. marpetgeo.2016.06.011

51. Mørk A et al (1999) Mesozoic lithostratigraphy. In: Dallmann WK (ed) Lithostratigraphic Lexicon of Svalbard. Review and Recommendations for Nomenclature. Use Upper Paleozoic to Quaternanry Bedrock. Norsk Polarinstitutt, Troms $\emptyset$, pp 127-214

52. Muller TM, Gurevich B, Lebedev M (2010) Seismic wave attenuation and dispersion resulting from wave-induced flow in porous rocks-a review. Geophysics 75:A147-A164. doi:10. $1190 / 1.3463417$

53. Nøttvedt A, Berglund T, Rasmussen E, Steel R (1988) Some aspects of Tertiary tectonics and sediments along the western Barents shelf. In: Morton AC, Parson LM (eds) Early Tertiary volcanism and the opening of the NE Atlantic, vol 39. Geological Society Special publication, pp 421-425 
54. Nyland B, Jensen LN, Skagen J, Skarpnes O, Vorren T (1992) Tertiary uplift and erosion in the Barents Sea; magnitude, timing and consequences. Nor Pet Soc (NPF) 1:153-162

55. Ohm SE, Karlsen DA, Austin TJF (2008) Geochemically driven exploration models in uplifted areas: Examples from the Norwegian Barents Sea. Aapg Bull 92:1191-1223. doi:10.1306/ 06180808028

56. Olsen RG, Hansen OK (1987) Askeladd. In: Spencer AM et al (eds) Geology of the Norwegian oil and gas fields: Graham and Trotman, pp 419-428

57. Omer S (2013) Imaging reservoir quality of Alka discovery, Norwegian Barents Sea: Petrophysical, rock physical and AVO modeling approach, Master Thesis, Department of Geosciences, University of Oslo, Oslo, Norway. Published digitally through DUO (Digitale Utgivelser ved UiO). http://www.duo.uio.no

58. Ostanin I, Anka Z, di Primio R, Bernal A (2013) Hydrocarbon plumbing systems above the Snohvit gas field: structural control and implications for thermogenic methane leakage in the Hammerfest Basin SW Barents Sea. Mar Pet Geol 43:127-146. doi:10. 1016/j.marpetgeo.2013.02.012

59. Ostanin I, Anka Z, Primio RD, Bernal A (2012) Identification of a large upper cretaceous polygonal fault network in the Hammerfest basin: implications on the reactivation of regional faulting and gas leakage dynamics SW Barents Sea. Mar Geol. doi:10. 1016/j.margeo.2012.03.005

60. Ottesen D, Dowdeswell JA, Rise L (2005) Submarine landforms and the reconstruction of fast-flowing ice streams within a large Quaternary ice sheet: the 2500-km-long Norwegian-Svalbard margin $\left(57^{\circ}-80^{\circ} \mathrm{N}\right)$. Geol Soc Am Bull 117:1033-1050. doi:10. 1130/B25577.1

61. Perez-Garcia C, Feseker T, Mienert J, Berndt C (2009) The Hakon Mosby mud volcano: 330000 years of focused fluid flow activity at the SW Barents Sea slope. Mar Geol 262:105-115. doi:10.1016/j.margeo.2009.03.022

62. Planke S, Bunz S, Berndt C, Eriksen OK, Eriksen FN, Lie JE (2013) P-Cable High-Resolution 3D Seismic Imaging of Gas Hydrates and Shallow Gas 75th EAGE Conference \& Exhibition incorporating SPE EUROPEC 2013, London, UK, 10-13 June 2013

63. Quintal B, Steeb H, Frehner M, Schmalholz SM (2011) Quasistatic finite element modeling of seismic attenuation and dispersion due to wave-induced fluid flow in poroelastic media. J Geophys Res 116:B01201. doi:10.1029/2010JB007475

64. Rajan A, Bunz S, Mienert J, Smith AJ (2013) Gas hydrate systems in petroleum provinces of the SW-Barents Sea. Mar Pet Geol 46:92-106. doi:10.1016/j.marpetgeo.2013.06.009

65. Riis F, Fjeldskaar W (1992) On the magnitude of the late Tertiary and Quaternary erosion and its significance for the uplift of Scandinavia and the Barents Sea. In: Larsen RM, Brekke H, Larsen BT, Telleraas E (eds) Structural and Tectonic Modelling and its Application to Petroleum Geology. Elsevier, Amsterdam, pp $163-185$

66. Rise L, Bellec VK, Chand S, Boe R (2014) Pockmarks in the southwestern Barents Sea and Finn mark fjords Norw. J Geol 94:263-282

67. Roberts SJ, Nunn JA (1995) Episodic Fluid Expulsion from Geopressured Sediments. Mar Pet Geol 12:195-204

68. Rodrigues-Duran E, Di Primio R, Anka Z, Stoddart D (2013) 3Dbasin modelling of the Hammerfest Basin (southwestern Barents Sea): a quantitative assessment of petroleum generation, migration and leakage. Mar Petrol Geol 45:281-303

69. Sanaz J (2013) Petrography and petrophysical well log interpretation for evaluation of sandstone reservoir quality in the Skalle well (Barents Sea) Master Degree Thesis. Norwegian University of Science and Technology, Department of Geology and Mineral Resources Engineering
70. Schowalter TT (1979) Mechanics of secondary hydrocarbon migration and entrapment. AAPG Bull 63:723-760

71. Shakhova N, Semiletov I, Salyuk A, Yusupov V, Kosmach D, Gustafsson O (2010) Extensive Methane Venting to the Atmosphere from Sediments of the East Siberian Arctic Shelf. Science 327:1246-1250. doi:10.1126/science.1182221

72. Shi JQ, Imrie C, Sinayuc C, Durucan S, Korre A, Eiken O (2013) Snøhvit $\mathrm{CO}_{2}$ storage project: Assessment of $\mathrm{CO}_{2}$ injection performance through history matching of the injection well pressure over a 32-months period Energy Procedia

73. Sibson RH (2000) Fluid involvement in normal faulting J Geodyn 29:469-499

74. Smelror M, Petrov O, Larssen GB, Werner S (2009) Geological history of the Barents Sea Geological Survey of Norway. Trondheim, Norway

75. Solheim A, Kristoffersen Y (1984) The physical environment Western Barents Sea, 1:500000. Sediments above the upper regional unconformity: thickness, seismic stratigraphy and outline of the glacial history. Norsk Polarinsitutt Skrifter 179B:1-26

76. Solomon $\mathrm{S}$ et al (2007) Contribution of working group i to the fourth assessment report of the intergovernmental panel on climate change. Cambridge University Press, Cambridge

77. Steffen R, Steffen H, Wu P, Eaton DW (2014) Stress and fault parameters affecting fault slip magnitude and activation time during a glacial cycle. Tectonics 33:1461-1476. doi:10.1002/ 2013tc003450

78. Stiansen JE, Filin AA (2007) Joint PINRO/IMR report on the state of the Barents Sea ecosystem 2006, with expected situation and considerations for management: IMR/PINRO Joint Report Series No. 2/2007. ISSN 1502-8828, p 209

79. Sund T (1984) Tectonic Development and Hydrocarbon Potential Offshore Troms, Northern Norway. Aapg Bulletin Am Assoc Pet Geol 68:1206

80. Svendsen JI, Gataullin V, Mangerud J, Polyak L (2004) The glacial history of the Barents and Kara Sea region. In: Ehlers J, Gibbard P (eds) Quaternary glaciations-extent and chronology. vol 1. Europe, Elsevier, Amsterdam, pp 359-368

81. Turcotte DL, Schubert G (2002) Geodynamics, 2nd edn. Cambridge University Press, Cambridge

82. Vadakkepuliyambatta S, Bünz S, Mienert J, Chand S (2013) Distribution of subsurface fluid-flow systems in the SW Barents Sea. Mar Pet Geol. doi:10.1016/j.marpetgeo.2013.02.007

83. Vorren TO, Landvik JY, Andreassen K, Laberg JS (2011) Chapter 27-Glacial History of the Barents Sea Region. In: Jürgen Ehlers PLG, Philip DH (eds) Developments in Quaternary Sciences, vol 15. Elsevier, pp 361-372. doi:10.1016/B978-0-44453447-7.00027-1

84. Winsborrow MCM, Andreassen K, Corner GD, Laberg JS (2010) Deglaciation of a marine-based ice sheet: Late Weichselian palaeo-ice dynamics and retreat in the southern Barents Sea reconstructed from onshore and offshore glacial geomorphology. Quat Sci Rev 29:424-442. doi:10.1016/j.quascirev.2009.10.001

85. Winsborrow MCM, Andreassen K, Corner GD, Laberg JS (2010) Deglaciation of a marine-based ice sheet: late Weichselian palaeoice dynamics and retreat in the southern Barents Sea reconstructed from onshore and offshore glacial geomorphology (vol 29, pg 424. Quat Sci Rev 29:1501. doi:10.1016/j.quascirev.2010.03.009

86. Worsley D, Johansen R, Kristensen SE (1988) The Mesozoic and Cenozoic succession of Tromsøflaket. In: A Lithostratigraphic Scheme for the Mesozoic and Cenozoic Succession Offshore Mid- and Northern Norway, Norwegian Petroleum Directorate Bulletin No. 4, pp 42-65

87. Zieba KJ, Grøver A (2016) Isostatic response to glacial erosion, deposition and ice loading. Impact on hydrocarbon traps of the southwestern Barents Sea Marine and Petroleum Geology 78:168-183. doi:10.1016/j.marpetgeo.2016.09.009 